NBER WORKING PAPER SERIES

\title{
INTERNATIONAL TRADE AND INSTITUTIONAL CHANGE: MEDIEVAL VENICE'S RESPONSE TO GLOBALIZATION
}

\author{
Diego Puga \\ Daniel Trefler \\ Working Paper 18288 \\ http://www.nber.org/papers/w18288
NATIONAL BUREAU OF ECONOMIC RESEARCH
1050 Massachusetts Avenue
Cambridge, MA 02138

August 2012

We are thankful to Lisa Chen and Jennifer Konieczny for excellent research assistance. We are grateful to our colleagues in the Institutions, Organizations and Growth Program at the Canadian Institute for Advanced Research (CIFAR), including Daron Acemoglu, Mauricio Drelichman, Elhanan Helpman, Joel Mokyr, Jim Robinson, and especially Avner Grief. We have benefited from conversations with Abhijit Banerjee, John Munro, Dorit Raines, Nathan Sussman, Aloysius Siow, Bob Staiger, Jeff Williamson and patient participants at many workshops. Yadira González de Lara provided us with detailed, repeated and essential feedback. Trefler thanks CIFAR and the Social Sciences and Humanities Research Council of Canada (SSHRC) for financial support. Puga thanks the European Commission's Seventh Research Framework Programme for the European Research Council's Advanced Grant 'Spatial Spikes' (contract number 269868) and for the Collaborative Project HI-POD (contract number 225343), the Banco de Espana Excellence Programme, the Comunidad de Madrid (grant S2007/HUM/0448 PROCIUDAD-CM) and the IMDEA Ciencias Sociales and Madrimasd Foundations for financial support. The views expressed herein are those of the authors and do not necessarily reflect the views of the National Bureau of Economic Research.

NBER working papers are circulated for discussion and comment purposes. They have not been peerreviewed or been subject to the review by the NBER Board of Directors that accompanies official NBER publications.

(C) 2012 by Diego Puga and Daniel Trefler. All rights reserved. Short sections of text, not to exceed two paragraphs, may be quoted without explicit permission provided that full credit, including $₫$ notice, is given to the source. 
International Trade and Institutional Change: Medieval Venice's Response to Globalization Diego Puga and Daniel Trefler

NBER Working Paper No. 18288

August 2012

JEL No. F1

\begin{abstract}
$\underline{\text { ABSTRACT }}$
International trade can have profound effects on domestic institutions. We examine this proposition in the context of medieval Venice circa 800-1350. We show that (initially exogenous) increases in long-distance trade enriched a large group of merchants and these merchants used their new-found muscle to push for constraints on the executive i.e., for the end of a de facto hereditary Doge in 1032 and for the establishment of a parliament or Great Council in 1172. The merchants also pushed for remarkably modern innovations in contracting institutions (such as the colleganza) that facilitated large-scale mobilization of capital for risky long-distance trade. Over time, a group of extraordinarily rich merchants emerged and in the almost four decades following 1297 they used their resources to block political and economic competition. In particular, they made parliamentary participation hereditary and erected barriers to participation in the most lucrative aspects of long-distance trade. We document this 'oligarchization' using a unique database on the names of 8,103 parliamentarians and their families' use of the colleganza. In short, long-distance trade first encouraged and then discouraged institutional dynamism and these changes operated via the impacts of trade on the distribution of wealth and power.
\end{abstract}

\author{
Diego Puga \\ Centro de Estudios Monetarios y Financieros (CEMFI) \\ Casado del Alisal 5, \\ 28014 Madrid \\ Spain \\ and CEPR \\ diego.puga@cemfi.es \\ Daniel Trefler \\ Rotman School of Management \\ University of Toronto \\ 105 St. George Street \\ Toronto, ON M5S 3E6 \\ CANADA \\ and NBER \\ dtrefler@rotman.utoronto.ca
}




\section{Introduction}

Venice has always presented two faces. As a great medieval trading centre its wealth was used to build not only beautiful architecture, but also remarkably modern institutions. This is nowhere more obvious than in the Doge's palace, whose grand Sala Maggiore housed a parliament (established in 1172) composed of the rich merchants that monitored and constrained most of the Doge's activities. But climb up to the top floor of the palace and one enters the clandestine rooms of the secret service. With each passing decade after its establishment in 1310, this secret service was used to buttress the powers of a smaller and smaller number of families whose spectacular wealth was fed by international trade. This paper tracks the evolution of Venice's pre-1300 growth-enhancing institutional innovations and then Venice's loss of institutional dynamism after 1300. Our main thesis is that both these developments were the outcome of a single shock, the rise of international trade. International trade led to an increased demand for growth-enhancing institutions, but trade also led to a shift in the distribution of income that allowed a group of increasingly rich and powerful merchants to derail institutional dynamism in their quest to capture the rents associated with international trade.

Two strands of the literature are particularly relevant to this thesis, one dealing with medieval European trade (Greif, 2006a) and the other with the Atlantic trade (Acemoglu, Johnson, and Robinson, 2005). Medieval Europe experienced a massive expansion of long-distance trade during the 'Commercial Revolution' of 950-1350 e.g., de Roover (1965), Lopez (1971) and North and Thomas (1973). At the same time, medieval Europe also embarked on a set of major institutional reforms that laid the groundwork for the Rise of the West. Greif $(1992,1994,2006 a, b)$ establishes a causal connection between institutions and long-distance trade: Europe's initial institutions facilitated the expansion of long-distance trade and, more importantly for our thesis, the resulting expansion of trade created a demand for novel trade- and growth-enhancing institutions. These included property-right protections that committed rulers not to prey on merchants (see also Greif, Milgrom, and Weingast, 1994), a nascent Western legal system that included a corpus of commercial law known as the Law Merchant (see also Milgrom, North, and Weingast, 1990), publicly provided monitoring and enforcement of commercial contracts (González de Lara, 2008), and self-governing bodies such as business corporations. All of these are hallmark institutions of the Rise of the West.

Turning to Early Modern Europe, Acemoglu et al. (2005) show that where pre-1500 political institutions placed significant checks on the monarchy, the growth of the Atlantic trade strengthened merchant groups to the point where they were strong enough to further constrain the power of the monarchy. The English Civil War and the Glorious Revolution are the most famous examples (Jha, 2010; Acemoglu and Robinson, 2012, chapter 7). After 1800, this improvement in property rights raised urbanization rates and GDP per capita. ${ }^{1}$

\footnotetext{
${ }^{1}$ Rajan and Zingales (2003), who deal with the twentieth century rather than older historical periods, show that foreign competition prevented domestic incumbents in financial markets from erecting barriers to entry. Thus, more open economies were less likely to experience the deterioration in financial institutions that plagued so many midtwentieth century economies.
} 
The above research is pervaded by two themes that will be important for our analysis. First, institutional change occurs not because it is efficient, but because it is advanced by powerful special interests. ${ }^{2}$ Second, as trade grows it affects the domestic distribution of income and hence the relative power of competing special interests. It is this change in relative power that drives institutional change. ${ }^{3}$

\section{The Story of Venice}

In order to deepen our understanding of the impacts of long-distance trade, via income distribution, on long-run institutional dynamics, we turn to a detailed historical and statistical examination of Venice during the Commercial Revolution. The broad outlines of Venetian history that we use to support our thesis are as follows. Through a series of fortunate events in the ninth century, Venice became politically independent. This, together with Venice's fortunate geography, uniquely positioned it to benefit from rising trade between Western Europe and the Levant. These two factors combined to enrich Venetian merchants, who used their new-found economic muscle to push for institutional change.

The two key dates for improvements in property rights institutions are 1032, which marks the end of a de facto hereditary Dogeship and 1172, which marks the establishment of a Venetian parliament that was the ultimate source of political legitimacy. Contracting institutions also displayed extraordinary dynamism during the Commercial Revolution, in part to deal with the commitment and enforcement problems that come with doing business abroad (Milgrom et al., 1990; Greif et al., 1994; Greif, 2006a), but also to deal with the unique demands placed on capital markets by long-distance, seaborne trade. This risky trade required large capital outlays that literally sailed out of sight and this in turn led to the development of new business forms and legal innovations that supported the mobilization and allocation of capital. One particularly famous innovation was the limited-liability partnership known as the colleganza in Venice and the commenda elsewhere in Europe. It was the direct precursor of the great joint stock companies of a later period. Importantly for our thesis, it allowed even relatively poor merchants - who had neither capital nor collateral — to engage in long-distance trade.

These institutional improvements made Venice wealthier overall, but also led to substantial changes in the Venetian distribution of income. For one, the riskiness of trade together with the widespread involvement of Venetians in this trade, created a great deal of income churning mostly rags to riches but also some riches to rags. For another, a small group of merchant families grew spectacularly wealthy.

${ }^{2}$ This point is part of Acemoglu's (2003) broader discussion of why there is no political Coase theorem. See also North's (1990) related critique of North and Thomas (1973). This point is also part of Greif's notion of 'coercionconstraining institutions' (Greif, 2005, 2008; González de Lara, Greif, and Jha, 2008).

3 See Acemoglu (2008), Acemoglu, Bautista, Querubín, and Robinson (2008), and especially Acemoglu and Robinson (2006, chapter 10) who examine how changes in economic and political inequality affect economic development and transitions to democracy. See also Greif and Laitin (2004) and Greif (2006a) who study the role of changing income distribution for institutional change in a comparative study of Venice and Genoa. Do and Levchenko (2009) and Levchenko (forthcoming) develop important theoretical models of the impact of trade, via rent creation and the power it confers, on institutions. 
This brings us to the great puzzle of Venetian history: its remarkable institutional dynamism fell off sharply during the period 1297-1323. This defining epoch in Venetian history, known as the Serrata or 'closure,' brought Venetian politics under the control of a tightly knit cabal of the richest families. It was, in Norwich's (1977) words, the triumph of the oligarchs. Further, by the early 1330 s this political closure had spilled over into an economic closure that excluded poorer families from participation in the most lucrative aspects of international trade. Venetian property-right institutions had taken one large step backwards and her contracting institutions had lost their dynamism.

To understand this puzzle, we construct a model that highlights the key role played by the evolution of income distribution. To this end, we introduce political and coercive institutions into a version of the Banerjee and Newman (1993) framework of occupational choice and income dynamics (see also Galor and Zeira, 1993).4 In our model, as was the case in medieval Venice, political power is tied to mercantile wealth and participation in international trade is limited by wealth constraints (the poor cannot self-finance) and possibly by legislation (the poor can be excluded from long-distance trade).

Along the model's equilibrium path there is economic and political mobility until the wealthiest merchants are powerful enough as a group to restrict entry into political markets. However, long-distance trade continues to generate wealth for up-and-coming merchants, which poses a political and economic threat to the wealthiest merchants. To prevent this without triggering a revolt, the wealthiest merchants co-opt the nouveau riche by allowing them into the Great Council. (In the model, this enlargement happens only once; likewise in the historical record.) This larger coalition then restricts participation in long-distance trade to Great Council members. That is, barriers to entry into both political and economic markets are erected. The resulting evolution of the distribution of income (and hence of coercive power), permanently supports this outcome.

We show empirically how this replicates the sequence of historical events associated with the Serrata of 1297-1323. The key outcome of the Serrata was the creation of a hereditary nobility that had the exclusive right to serve in the Great Council and used this right to restrict participation in long-distance trade. To deepen our understanding of the Serrata, we develop a database consisting of the 8,103 elected members of the Great Council in the period immediately preceding the Serrata (1261-1295). We use this to show that mobility was indeed eroding the political position of the wealthiest families. In particular, they were losing seats to up-and-coming families who had not previously been involved in politics. This is the first systematic use of these complex data. Building on Kedar (1976) and González de Lara (2008), we also code up the hundreds of colleganza contracts for long-distance trade that have survived from the period 1073-1342. We use this to show that economic restrictions enacted during the Serrata were effective not only in restricting the use of the

4The importance of the interaction between politics and economics in credit-constrained economies has been investigated by de Soto (1989) and Besley, Burchardi, and Ghatak (2012). 
colleganza to the newly created nobility, but in restricting it to the most powerful of these nobles. ${ }^{5}$

Despite the fact that the Serrata was a major step backwards for property-right and contracting institutions, it did not bring Venice's economic and social successes to an end. But it did fundamentally alter the nature of these successes. Venice continued to engage in international trade; however, relative to its pre-Serrata path, a smaller fraction of its population was involved in long-distance trade, the wealth distribution became more polarized, and social, political and economic mobility evaporated. This is precisely what the model predicts and the historical record shows.

\section{Contributions and Connections}

Our thesis makes a number of contributions to the literature. First, we show that the single shock of rising long-distance trade initially led to institutional dynamism and then, after the Serrata, to a loss of this dynamism. Thus, trade can have positive effects, negative effects, or as in Venice, first positive and then negative effects. Second, using data on participation in parliament and long-distance trade, we more precisely pin down the pre- and post-Serrata special interest groups that drove institutional change. Third, whereas in Acemoglu et al. (2005), initial property-right institutions are exogenous, in the Venetian case their early development can be traced back to the growth of long-distance trade.

This introduction leaves a question hanging. If institutions are so important for long-term growth, why did Venice not immediately decline after the Serrata? This is all the more puzzling given the costs of oligarchization that Venice appears to have borne i.e., a loss of entrepreneurialism and 'oligarch-biased' technical change (Acemoglu, 2008). The answer is that oligarchization helped Venice by putting a lid on the destructive inter-clan rivalries that so ravaged other European communes. Here our analysis dovetails tightly with that of Lane (1971, pages 259-260), Greif (2006a, section 6.4) and González de Lara (2008) who emphasize the role of these rivalries. See section 7 .

Sections 2-4 review Venice's early history and the rise of property-right and contracting institutions. Section 5 presents the model. Section 6 reviews the Serrata and presents our empirical results. Section 8 concludes.

\section{A Brief History, $800-1297$}

This section provides a brief overview of Venetian history, with a focus on Byzantium since it played an essential role and its history will be less familiar to many readers.

\footnotetext{
5This aspect of our paper is related to Jha's (2010) analysis of the English Long Parliament (1640-1660). He uses detailed data on parliamentarians to examine the formation of the coalition that supported stronger constraints on the Crown. Using data on the investments of about 500 parliamentarians, Jha finds that a particular financial innovation shares in overseas companies - allowed broader investor participation in overseas trade and thus was key in aligning interests against royal discretion over foreign economic affairs. This is similar to the longer-term role the colleganza played in Venice before (but not after) the Serrata.
} 
Figure 1: Medieval Shipping Lanes of the Eastern Mediterranean

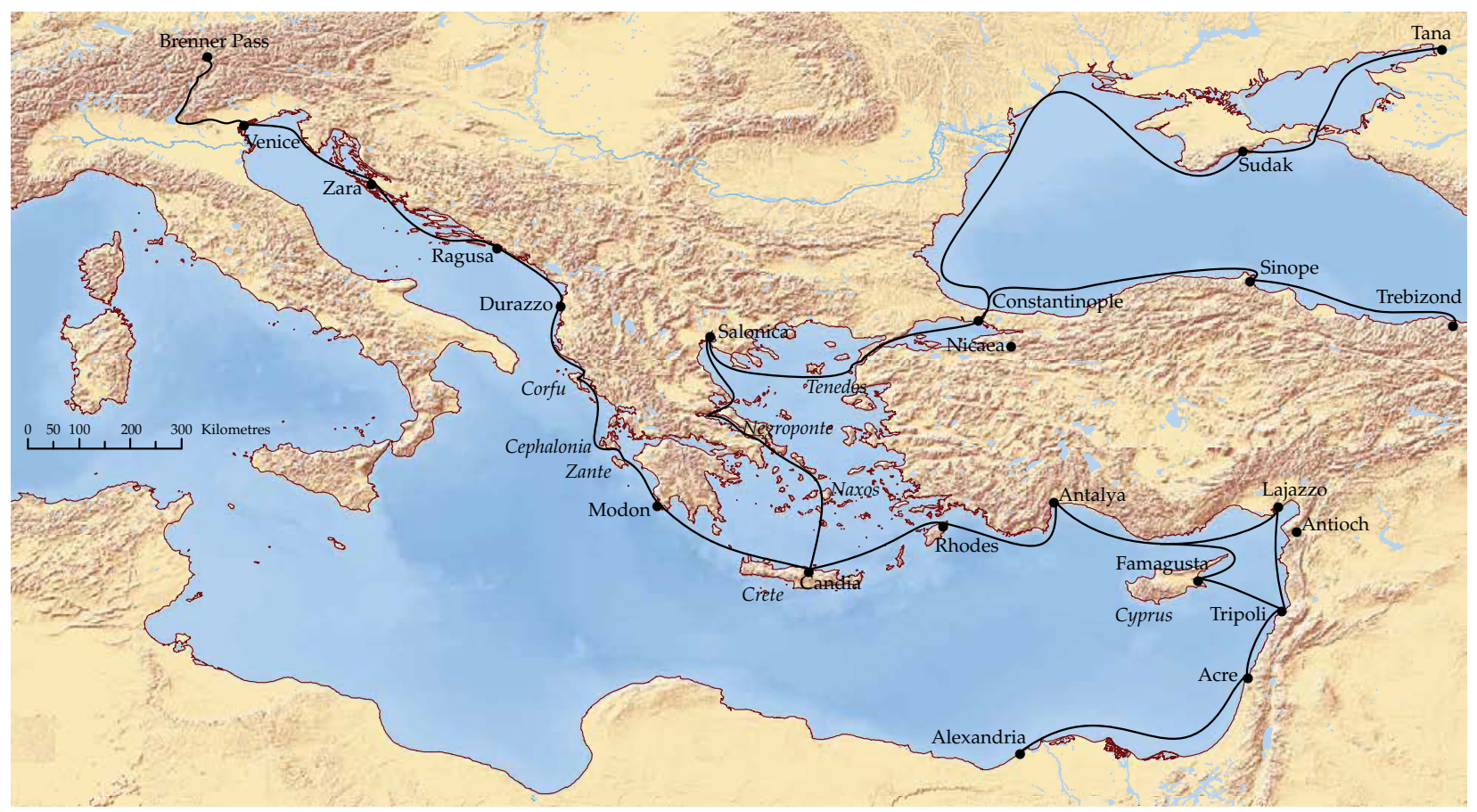

\section{A Political Sovereignty, 800-992}

Venice was the only significant part of the Italian peninsula that was not conquered by the many barbarian invasions of the fifth to eighth centuries. Even though Venice was only a swampy backwater, in 800 it had the dubious distinction of being the westernmost outpost of Byzantium. The crowning of Charlemagne in 800 heralded the re-emergence of a strong political entity in Western Europe and drew the ire of the Byzantine emperor. Not surprisingly, the first military conflict between the Western and Eastern empires took place in the lagoon along the beautiful beaches of the Lido. Charlemagne's troops were turned back by a joint Venetian-Byzantine force and, in the resulting peace treaty of 814 , Charlemagne renounced all claim to Venice. Further, Byzantium acknowledged Venetian help by granting it de facto independence. Over the next two centuries Venice repeatedly helped Byzantium in its battles with the Arabs and was rewarded with official independence in the Golden Bull of 992. See Nicol (1988).

In short, through a "series of fortuitous events" (Cessi, 1966, page 261) Venice achieved unusual freedom from the external political and military influences that plagued the Italian peninsula and indeed, most of Europe. This allows us as researchers to observe five centuries of history during which Venice's merchants would push for political reforms free from the external military threats of East and West. 


\section{B The Reemergence of Long-Distance Trade, 969-1082}

It turns out that the Dark Ages were not so dark. By the middle of the tenth century, Europe had shaken off its slumber and stepped onto the threshold of a 'Commercial Revolution' that would last four hundred years (Lopez, 1971, North and Thomas, 1973). A big part of this revolution was the rise of long-distance trade between Western Europe and the Levant (including Byzantium). Venice was again lucky: it was strategically positioned on a major and ancient route from Constantinople to Western Europe that went through the lagoon, up the Adige River into the Alps, over the Brenner Pass, and down into the Rhine and Danube basins. See figure 1 .

The economic rise of Western Europe was an unexpected boon to Venice. In the eleventh century, the Rhine and Danube were home to four of the five largest cities in Western Europe. ${ }^{6}$ Closer to home, the Venetian lagoon dominated the mouths of the key navigable rivers of Lombardy (the Po, Brente, and Adige rivers), thus allowing Venice to control the carriage trade (wheat, salt and timber) of an economically dynamic region that stretched westward to Milan.

To the east lay Byzantium, inheritor of Rome's mantle. Venice was strategically placed midway between Byzantium and the West and so was Constantinople's natural trading partner. In 10oo, Constantinople was Christian Europe's greatest industrial centre and its richest city. Its population of roughly 300,000 was as large as the combined populations of the next 1o largest cities in Christendom. ${ }^{7}$ Unfortunately for Venice, large-scale trade in the Eastern Mediterranean was not an option before 969. In an era when ships sailed within sight of land and were beached at night, Arab control of Syria, Cyprus, Crete and Sicily allowed Arab pirates to plunder the Aegean and Ionian coastlines and seas, making Christian shipping far too dangerous (Rotman, 2009). It also blocked much of the Levant trade. In short, the Arabs dominated the main Mediterranean sea lanes. See figure $1 .^{8}$

All this changed at a dizzying rate when, between 961 and 969, a resurgent Byzantium regained control of the Eastern Mediterranean sea lanes by conquering Syria, Crete and Cyprus. Largerscale trade between Venice, Constantinople and the Levant quickly re-emerged. As Pryor (1988, page 111) writes of these conquests: "Christian reconquest of the Muslim possessions along the trunk [main shipping] routes in the tenth and eleventh centuries laid the foundations for the later Western domination of those routes, with all that implied. The reconquest thus appears as one of the most fundamentally important historical processes in Mediterranean history." 9

From 969 on Venetian long-distance trade expanded steadily; however, everything was accelerated after 1082. In that year, a remarkable confluence of exogenous events on distant shores

\footnotetext{
${ }^{6}$ Regensburg on the Danube (population 40,000) and Mainz $(30,000)$, Speyer $(25,000)$ and Cologne $(21,000)$ on the Rhine. Merchants from London $(25,000)$ and Paris $(20,000)$ were not on this route, but could be met at the Champagne Fairs (today in eastern France). Population data are from De Long and Shleifer (1993, table 1).

7These 10 cities combined had a population of 291,00o. See De Long and Shleifer (1993, table 1). Venice had a population of 45,00o. Data for Constantinople are from Chandler (1987).

${ }^{8}$ Pryor (1988) provides a detailed explanation of how these sea lanes were determined by prevailing winds, limited sailing technologies, and the availability of ports with shelter and fresh water.

9 Venice had one last piece of good luck, one that is rarely mentioned in tour guides: Venice was heavily involved in the slave trade. In 969, many Slavs were still pagan and fair game for slaving. (The similarity between 'Slav' and 'slave' is no coincidence.) Slavs were captured on Venice's northwestern doorstep and transhipped via Venice to Constantinople and Islamic countries (Rotman, 2009). The slave trade remained important to Venice for many centuries.
} 
propelled Venice into a period of unprecedented prosperity and 'globalization.' The events began in the Near East. In 1071, the Byzantine resurgence in the Near East was dramatically reversed by the Battle of Manzikert, which brought the Seljuk Turks to Nicaea, a stone's throw from the gates of Constantinople. In the West, the Normans ousted Byzantine forces from Southern Italy in 1071 and in 1081-1082 they set their sights on Constantinople, crossing the Adriatic and marching on Constantinople.

In the ensuing panic, a military man was installed as the new Byzantine emperor. He immediately enlisted Venice - a long-time ally and mutual foe of the Normans - to disrupt the Norman's Adriatic crossing. Byzantium was in dire straights and Venice extracted a heavy price for its naval involvement. The Golden Bull of 1082 granted Venice duty-free access to 23 of the most important Byzantine ports and granted Venetian merchants property-right protections from the caprices of corrupt Byzantine administrators. Most importantly, the Venetians were given buildings and wharfs within Constantinople. That is, Venetians become the first foreign traders in Constantinople to have their own Quarter. See Brown (1920) for details. Over the next century the Quarter would become home to a staggering 20,000 Venetian merchants. The 1082 Golden Bull was crucial to this Venetian maritime expansion. ${ }^{10}$

Summarizing, the rise of Venetian long-distance trade was initially driven by exogenous factors: the economic rise of Western Europe and the resurgence of Byzantium, both in the second half of the tenth century; Christian conquest of Mediterranean sea lanes after 969; and the Golden Bull of 1082. To be even more reductionist: Venetian trade expanded sharply after two exogenous events, those of 969 and 1082.

\section{Colonial Empire and Nobility Rents, 1082-1297}

After 1082, Venice entered a two-centuries long period of expansion into the Eastern Mediterranean. This expansion necessarily generated tensions between Venice and Constantinople. These became increasingly serious after 1148 and came to a head on the night of March 12, 1171 when the Byzantine emperor rounded up 10,000 Venetians residing in the Empire and announced that they were being held for ransom. ${ }^{11}$ The hostage crisis precipitated Venice's greatest constitutional crisis, a point of importance which we discuss below. It also increased Venetian belligerence towards Constantinople, which culminated in the Venetian-led Fourth Crusade. On April 12, 1204 the blind Doge Enrico Dandolo ordered his galley beached under the walls of Constantinople and urged his men up and over. They entered the history books as the first foreigners ever to enter Constantinople by force. Constantinople fell and in the upheaval that followed, Venice grabbed a vast swath of colonies spread throughout the Aegean, Eastern Mediterranean and Black Seas.

\footnotetext{
${ }^{10}$ Note that the Bull was due to the temporary weakness of Byzantium, not the strength of Venice. Venetian involvement in the 1081-1082 campaign was a military disaster and the Normans eventually turned back voluntarily in order to quell an uprising back home in Southern Italy.

${ }^{11}$ These events are described by the contemporary Byzantine historian Choniates. See Choniates (1984, pages 50-51, 97-98). The figure of 10,000 is from the early thirteenth-century Historia Ducum Veneticorum which is reprinted in Berto (1999, chapter 18). This is also the source of the above figure of 20,000: "Exierunt autem anno illo fere viginti milia Venetorum in Romaniam."
} 
Over the next half century, upwards of 70,000 Venetians would migrate to these colonies, creating a vast commercial network within a colonial empire.

To run its colonial empire, Venice quickly established a colonial bureaucracy. At its apex stood a relatively small number of chief colonial administrators. ${ }^{12}$ They occupied extraordinarily lucrative offices: large salaries were paid by the Venetian state (e.g., Robbert, 1994, tables 4-8) and officeholders "usually mixed business with politics" (Lane, 1973, page 141). Rösch (1989, pages 160-161) documents that within just three years of the 1204 conquest, nine Venetians had already earned vast profits. By the time of the Serrata in 1297-1323, chief colonial administrators were drawn exclusively from the richest families of the newly formed nobility ( $\mathrm{O}^{\prime}$ Connell, 2009, chapter 2). We therefore refer to the benefits of officeholding as 'nobility rents.' There were many other forms of nobility rents and we focus on just this one for simplicity. ${ }^{13}$

\section{Domestic Institutional Change: Constraints on the Executive}

We argue in the next two sections that the expansion of long-distance trade initially promoted positive domestic institutional change. In this section we focus on constraints on the executive (property rights) and in the next on contracting institutions.

\section{A The End of a Hereditary Doge, 1032}

Venice is famous for its popular election of a Doge. Yet for the two centuries following Byzantium's first recognition of a local Doge in 814, all Doges were members of just three families. ${ }^{14}$ The common claim that early Venice was a democracy is nothing but a myth: a hereditary Dogeship was the rule. Venice had a "monarchical regime" (Cessi, 1966, page 270) and "the Doge was a monarch of unlimited power" (Lane, 1973, page 90).

Cracks in Dogal power began to appear in 976 when Doge Candiano IV was hunted down and murdered. His feudal interests on the mainland, his attempts to maintain power by courting the Holy Roman Emperor, and especially his resulting conflicts with the Byzantine Emperor were too much for the growing group of merchants who depended heavily on Byzantine trade. See Nicol (1988, chapter 3). Early Doges would not have pandered to these merchants. However, the securing of Mediterranean shipping lanes in the 96os and the resulting increase in long-distance trade had substantially altered the distribution of power through its impact on the wealth of merchants.

\footnotetext{
${ }^{12}$ These included the Sanudos in Naxos, the Ghisi in Tinos and Mykonos, Marco Dandolo in Andros, Leonardo Foscolo in Anaphe, Marco Venier in Cerigo, Iacopo Barozzi in Santorini, Iacopo Viear in Cerigotto and, of course, the Corners in Crete. See O'Connell (2009, page 18).

${ }^{13}$ Nobility rents are famously documented by Queller (1986) who argues that the nobility used the Great Council corruptly and to great personal advantage. Other examples of nobility rents include a welfare system that transferred public funds to impoverished members of noble families, the use of influence peddling, and the subsidization of the nobility-dominated galley trade. See Queller and, on the subsidization, O'Connell (2009, page 5).

${ }^{14}$ The three families were the Participazios, Candianos, and Orseolos. Other names appearing in the list of Doges were individuals who were related by marriage to one of these three families. See http://fmg.ac/projects/medlands/venice.htm\#_toc130481391. The sole exception was Pietro Tribuno (888-912).
} 
Evidence that a large number of wealthy merchants had 'arrived in society' can be gleaned from the lists of endorsers of ducal documents. These lists contain large numbers of new names. For example, in a 971 ducal document which unsuccessfully attempted to patch up deteriorating relations with the Emperor, there were 72 endorsers and $81 \%$ of them were new names. Further, the number of new names jumped substantially in the 1090s i.e., shortly after the 1082 Golden Bull. See Castagnetti (1992a) and especially Castagnetti (1992b, pages 625-626 and 637-638).

As the merchant class grew in size and power, Doges were increasingly constrained in their attempts to pursue self-interest at the expense of communal interests. In 1032, the political unrest initiated in 976 came to a head with the election of a Doge who was a wealthy silk merchant. His election brought an end to the system of hereditary Doges. Doges were banned from appointing their successor; a system of elections for Doges was put in place and enforced; and Doges were henceforth required to consult with two judges and abide by judicial decisions even on matters dealing with the Doge's private affairs. See Lane (1973, page 90) and Cessi (1966, pages 263 and 270). The first significant constraint on the executive was established and long-distance trade, through its impact on the distribution of wealth and power, was the key driver of this institutional innovation.

\section{B Establishment of a Parliament, 1172}

Between the reforms of 1032 and the hostage crisis of 1171, Venice experienced a massive expansion of its maritime commerce and power. The 1094 consecration of Saint Mark's Basilica, Venice's greatest architectural achievement, is a lasting testament to this expansion. Venetian merchants were growing rich from long-distance trade. With their burgeoning powers, the time was ripe for merchants to flex their political muscle. The hostage crisis of 1171 forced the issue.

As far as the merchant families were concerned, Doge Vital II Michele (1156-1172) was a liability. The Michele family had held the Dogeship for 52 of the last 76 years and, while the Dogeship had not yet passed from a father to a son, it was clear to all that constraints on the executive were being eroded. ${ }^{15}$ The hostage crisis in March of 1171 provided an unexpected opportunity to reassert those constraints. In September of 1171, Doge Vital II Michele headed a large armada that was to blockade and harass Constantinople until the hostages were released. The plan failed miserably and in May of 1172 the fleet returned in utter disarray, bringing with it a devastating plague. Venetian frustration was palpable and much of it was directed against the Doge. A certain Marco Casiolo was particularly frustrated - perhaps his family had been wiped out by the plague so frustrated that he followed the unarmed Doge down a side street and murdered him. It had been almost two centuries since a Doge had been murdered and the unexpected assassination left a power vacuum which the Ducal Councillors and leading merchant families immediately filled. Instead of electing a new Doge, they waited seven months until they had developed a constitution whose centrepiece was an elected parliament, known as the Great Council. As in Jones and Olken (2009), the assassination of an autocrat produced a transition to a more democratic regime.

\footnotetext{
${ }^{15}$ The Michele Doges were Vital I Michele (1096-1102), Domenico Michele (1117-1130), and his son-in-law Pietro Polani (1130-1148).
} 
To get a sense of the powers of this new legislative body, we review here the Council's power over the Doge. First, sometime between 1172 and 1192 the Great Council arrogated to itself the power to elect the Doge. The election rules, which evolved gradually, are memorable for their alternating use of randomizations and nominations; however, hiding behind this neat rule is something more fundamental - the Doge was elected by members of the Great Council. Second, on taking office the Doge was required to take an oath that explicitly listed what the Doge could not do e.g., expropriate state property or preside over cases against himself. The Great Council added to this list with the election of each new Doge (Madden, 2003, page 95-101, and Hazlitt, 1966, page 437). Third, in all important decisions, the Doge was required to consult with a six-member Ducal Council that was elected by and accountable to the Great Council. As Madden (2003, page 98) notes: "In short, by 1192 the doge could do almost nothing without approval of the council."

The establishment of the Great Council as the ultimate source of political legitimacy and the significant constraints imposed by the Oath of Office on Doges were major institutional innovations. For Norwich (1977, page 90) these were "arguably the most important reforms in Venetian history." They dramatically limited the power of the Doge and arrogated his powers to a large group of families who owed their wealth and power to long-distance trade.

\section{Domestic Institutional Change: The Rise of Contracting Institutions}

\section{A General Observations}

The two centuries following 1082 were ones of extraordinary dynamism for contracting institutions. By the early fourteenth century, financial innovations included: the appearance of limitedliability joint stock companies; thick markets for debt (especially bills of exchange); secondary markets for a wide variety of debt, equity and mortgage instruments; bankruptcy laws that distinguished illiquidity from insolvency; double-entry accounting methods; business education (including the use of algebra for currency conversions); deposit banking; and a reliable medium of exchange (the Venetian ducat). All these innovations can be related directly back to the demands of long-distance trade. ${ }^{16}$

Equally important is the development of a supporting legal and enforcement framework. The most discussed of these is the Law Merchant, which is universally accepted as the foundation of modern commercial law (Berman, 1983). Its very scope - the use of a court of peers to adjudicate commercial disputes between merchants travelling in distant lands - means that the Law Merchant was a direct and immediate response to the needs of long-distance trade (Kadens, 2004). ${ }^{17}$ The Commercial Revolution is also viewed as a key driver of the development of the modern Western legal tradition. This tradition has its origins in a legal revolution that occurred in the period 1075-1122 (Berman, 1983, Landau, 2004). While a general discussion of the origins

\footnotetext{
${ }^{16}$ See Weber (2003 [1889]), de Roover (1965), Lopez and Raymond (1967), Lopez (1971), Pryor (1981, 1988), Milgrom et al. (1990), Mueller (1997), Kohn (2005), and González de Lara (2008).

17This observation is further supported by the dating of the Law Merchant. Berman and Kaufman (2004) date its inception to the growth of trade in the eleventh century and cite the 1095 Amalphitan maritime code as its earliest written form. Documents that refer to substantive merchant law appear shortly after 1100 and by 1200 formal commercial courts appear (Kadens, 2004).
} 
of this legal tradition is outside the scope of this paper, a comment on timing is not. Civil law was not in use anywhere in Europe in 1000 (Radding and Ciaralli, 2006), but re-emerged in Europe in the second half of the twelfth century when communes began writing statutes governing their constitutions and commerce (Landau, 2004). The Doge's Oath of Office in 1172 is the first Venetian example of civil law that we are aware of. Second, the first half of the twelfth century witnessed an explosion of secular legal documents. Such documents were rare in 1050, but common by 1150. ${ }^{18}$ Venetian law developed rapidly thereafter: Its codification was begun under Doge Enrico Dandolo (1192-1205) and completed in 1242 by Doge Jacopo Tiepolo (1229-1249). See Besta and Predelli (1901).

Thus, civil law and commercial documents both appear just after long-distance trade began its explosive growth. There were other developments in Venetian contracting institutions in this period. See, for example, González de Lara (2008). Here we simply conclude that the expansion of trade after 1082 was accompanied, especially towards the end of the twelfth century, by a remarkable set of innovations in contracting institutions.

\section{B The Colleganza as an Institutional Response to the Demands of Long-Distance Seaborne Trade}

We now take an in-depth look at one particular contracting innovation, the colleganza. This was a predecessor of the joint-stock company and is viewed by all economic historians as one of the key commercial innovations of medieval times, if not the key innovation e.g., Lopez and Raymond (1967, page 174). Our aims in this subsection are threefold: (1) To discipline our discussion of institutional innovation by examining one innovation in detail; (2) To draw out the implications of long-distance trade for the evolution of income distribution; and, (3) To set the stage for the empirical work to come. To understand why the colleganza was such an innovation, one must first understand the mechanics of long-distance trade.

In travelling from Venice to the Eastern Mediterranean, the outbound trip averaged about one month and the return trip about two months (Pryor, 1988, page 52). Today these trips take three to four days, which gives a sense of the hardships of the voyage. Ships typically left Venice at the end of March when the winter storm season was finished and the prevailing winds had turned favourable. If all went well, ships arrived in Constantinople by the end of April, spent three weeks collecting merchandise for the voyage home, and arrived back in Venice by July. The goods brought back were then sold to merchants travelling to the late summer fairs in Central and Western Europe. See Lane (1966) and Lane (1973, pages 69-70). Such a trip, if on schedule, would have earned enormous profits, over 100 percent and sometimes much more.

While big returns could be had, there were also big risks. Death abroad from illness, shipwrecks, and piracy were common. There was also substantial business risk associated with the thinness of markets. A merchant who arrived in Acre a month late might find that the market was over for the year and be forced to dump his goods at fire-sale prices. Merchandise was not only sold, it was also bought for resale in Venice. Ships often travelled from port to port for months while merchants searched the hinterland for merchandise. Finally, weather delays alone could erase the

\footnotetext{
${ }^{18}$ For Venice, this is apparent from the collection of the earliest commercial contracts (Morozzo della Rocca and Lombardo, 1940). See Wickham (2003) and Radding (1988) for Tuscan and Lombard evidence, respectively.
} 
entire profit. By way of one simple example, if the outbound trip went smoothly, a ship that left for Acre in mid-March would be ready for the return trip by early June. However, once the prevailing winds shifted (some time in June) a ship could not sail out of Acre until late September. And if winter storms began early a ship would not reach Venice until the next Spring, effectively wiping out all profits. Thus, a merchant could easily walk away with big profits ... or big losses.

Unfortunately, long-distance trade required a large investment upfront. An appropriate-sized ship was 'in the top class of capital goods' (Lopez, 1971, page 80) and required extensive maintenance during its short life. Further, the cargo could be even more valuable than the boat itself. In 1100 , only the very richest Venetian families could afford to internally finance such an investment.

Long-distance seaborne trade thus placed unique demands on capital markets, demands that led to new contracting institutions which facilitated the large-scale mobilization and allocation of capital. Such trade had three characteristics. (1) It required large amounts of capital relative to most other contemporary private commercial activity such as agriculture or manufacturing. (2) Collateral was problematic because, unlike agriculture or manufacturing, the capital literally sailed out of sight. (3) Since the merchant was out of sight of investors, agency problems abounded (moral hazard and asymmetric information). The colleganza was a solution to these problems.

While there were many variants of the colleganza, we describe only the simplest and most common of these. There are two parties, the travelling merchant and the investor (or sedentary merchant). In Venice, the sedentary merchant gives wares (e.g., woollen cloth from Flanders) to the travelling merchant who then boards a ship with other merchants for an overseas destination, say Constantinople. In Constantinople, the travelling merchant sells the wares, uses the proceeds to buy other wares (e.g., pepper) and upon his return to Venice hands over the wares to the sedentary merchant. Any profits are split as pre-agreed.

A colleganza specifies the names of the two partners, itemizes the capital contributed by the sedentary merchant and/or gives it a value (this is the 'joint stock'), provides an itinerary of ports to be visited, and states how profits will be split. As soon as the travelling merchant returns to Venice the accounts of the partnership are settled and the partnership is dissolved. In the archetypical colleganza the sedentary merchant provides all the capital and receives $75 \%$ of the profits. The travelling merchant contributes no capital and receives $25 \%$ of the profits. If there are losses, these come out of the sedentary merchant's capital. If the losses exceed this capital, as would be the case if the travelling merchant incurred large debts overseas, then the sedentary merchant's obligations are limited by his initial investment. Restated, the colleganza provides limited liability and, specifically, the liability is limited to the joint stock of the partnership. This was a major innovation over Roman law and is widely recognized as the origins of the great joint stock companies of a later period.

Figure 2 provides a typical example. The sedentary merchant, Giovanni Agadi, puts up the joint stock of 300 pounds of Venetian pennies, an unimaginable sum for an ordinary Venetian. The travelling merchant, a young man by the name of Zaccaria Staniario, is to board a privately owned ship that will travel in convoy to Constantinople. No other commercial instructions are given: Staniario is in charge of all other decisions (including continuing his voyage to 'any other place that seems good to me') and this is why high-powered, profit-sharing incentives are needed. 


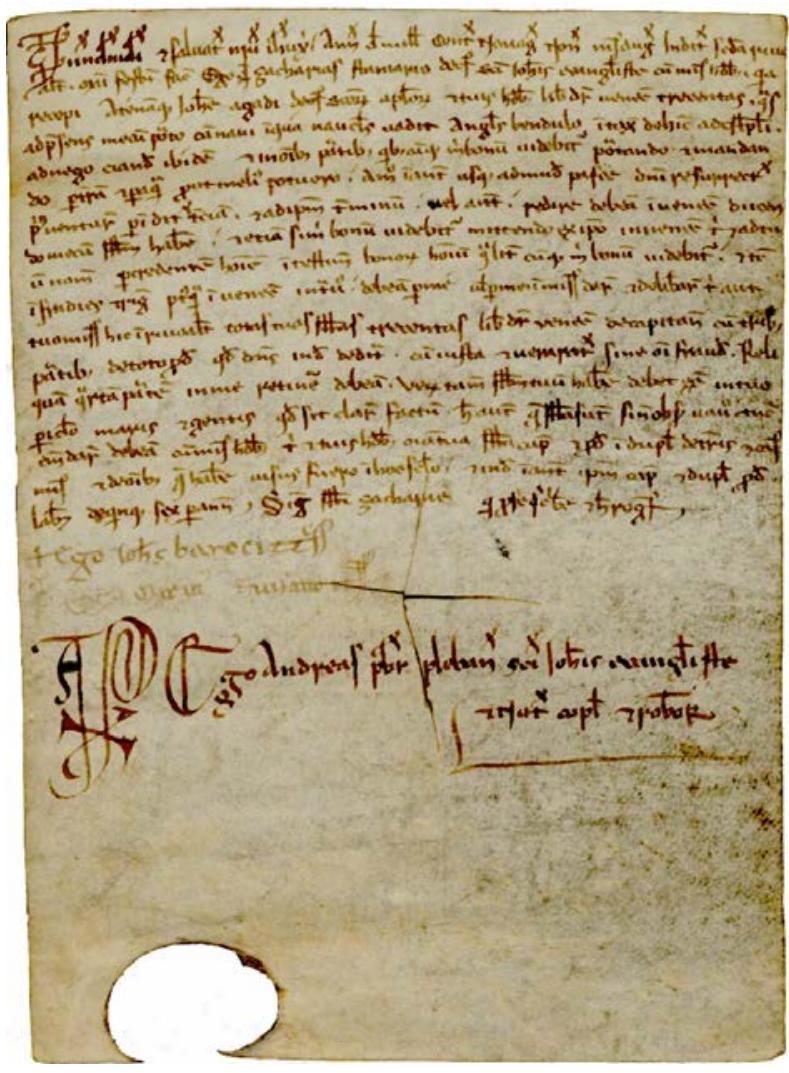

Original parchment document (above)

Authors' translation from the Latin (right)
In the name of the Lord God and of our Saviour Jesus Christ. In the year of the Lord 1199, in the month of August, second indiction, at Rialto. I, Zaccaria Staniario, from the ward of Saint John the Evangelist, together with my heirs, declare that I have received from you, Giovanni Agadi, from the ward of the Saint Apostles, together with your heirs, 300 pounds of Venetian pennies that I shall carry in the ship on which the helmsman Angelo Bendulo is traveling in convoy from here to Constantinople to do business there and in any other place that seems good to me, carrying and entrusting it through land and water as best I can until the next Paschal Resurrection of our Lord of the third indiction, and at that time or earlier I shall return to Venice carrying with me the aforesaid goods or else send you the same goods to Venice and on your behalf by whatever reliable man in the witness of good men seems good to me and then, within 30 days of having entered Venice, I am to give and deliver here in Rialto, personally or through my messenger, to you or to your messenger your entire capital of 300 pounds of Venetian pennies together with three parts of whatever profit God shall give us with just and truthful account and without any fraud. I am to keep for myself the remaining fourth. However, the aforesaid goods are to remain at your own risk from sea and people if this is clearly apparent. Moreover, if I do not observe all that is written above I am to compensate you and your heirs with double the amount of capital and profit out of my lands and houses and all that I am known to own in this world and let the same capital and the double bear interest of six per five every year from that time onwards. Signed by the aforementioned Zaccaria, who has asked this to be written on his behalf.

+ I, Giovanni Baroci, witness, signed.

+ I, Marino Trevisan, witness, signed.

I, Andreas, presbyter, parish priest at Saint John Evangelist and notary completed and certified this.

Figure 2: Colleganza between Zaccaria Stagnario and Giovanni Agadi, August 1199

The profit split is expressed in fractions: $3 / 4$ for the sedentary merchant and $1 / 4$ for he traveling merchant. If instead of profits there are losses, this downside risk is entirely borne by the sedentary merchant: 'at your own risk from sea and people'. The travelling merchant faces stiff penalties for failure to pay back the sedentary merchant. ${ }^{19}$

There is much that is not specified in this contract, so much so that the contract is hard to understand except in the context of supporting institutions that developed to support merchants travelling in colleganza. This point comes out in Pryor (1987, chapters III and IV), who reviews the resolution of hundreds of colleganza disputes in order to flesh out the full set of 'rules of the game' surrounding the colleganza. In addition, González de Lara (2008) reviews the private and public

\footnotetext{
${ }^{19}$ The penalty is double the amount of capital and profit plus a $20 \%$ annual interest $(6 / 5-1)$.
} 
institutions that supported the colleganza in the thirteenth century. ${ }^{20}$ Thus, the colleganza is not just a contract, it is an innovation that created a demand for other supporting institutions.

\section{Economic and Political Mobility: The Role of the Colleganza}

The discussion of this section has emphasized that long-distance trade was exceptionally complex and risky and could make or break a merchant. It has also emphasized that the institutional response - the colleganza - allowed poor merchants to enter the game. Indeed, most historians have commented on this feature of the colleganza e.g., de Roover (1965, page 51) who writes: "In a great many cases, the tractores [travelling merchants] were ambitious young men who were willing to take heavy risks in order to accumulate sufficient capital to join eventually the ranks of the stantes [sedentary merchants]."

As a result of the widespread engagement of the population in long-distance trade and the economic mobility it entailed, newly rich merchants flowed into political power throughout this period. This is a famous feature of Venetian society at this time. See Lane (1973, pages 20 and 89-90), Hazlitt (1966, page 216), Norwich (1977, pages 182-83), Ruggiero (1980, page 4) and Lopez (1971, pages 67-68 and 70). In Madden's (2003, page 3) words, "the membrane of Venetian nobility was permeable. Indeed, nobility in the sense of a group of families with a hereditary claim to political authority did not exist at all. In Venice, wealth, not land, defined nobility; commercial skill, not military prowess."

The life of Zaccaria Stagnario provides an example of the economic and political mobility that was possible at this time. His grandfather, Dobramiro, was a Croatian slave who was freed when his Venetian owner died. His father Pancrazio was a helmsman. In 1199 we find Zaccaria travelling in colleganza to Constantinople (this is the document we reproduced and translated in figure 2) and this experience paid off handsomely when he moved there after the 1204 conquest. By 1206 he held office as councillor to the first Venetian podestà in Constantinople and was rich enough to be a sedentary merchant in two colleganzas for the large sum of 200 Byzantine hyperpeppers, an amount equal to seven months salary of the Duke of Crete. Ironically for the grandson of a slave, these colleganza were for travel to the Black Sea fortress of Sudak, a slave-trading centre. Upon his

\footnotetext{
${ }^{20}$ Several examples make this point. First, limited liability is implied, but never expressed. Second, the largest expenses - shipping and cost of living for the merchant - are not even mentioned. Ships were often built by groups of merchants and these merchants held shares (locae): cargo space was allocated according to these shares and it was likely understood that the sedentary merchant paid for this (Pryor, 1987). Shares are mentioned in the earliest colleganza e.g., document 13 in Morozzo della Rocca and Lombardo, 1940. Byrne (1970) provides a detailed discussion of shares in a Genoese context. Shares were traded on secondary markets. Third, since a ship typically had many merchants aboard and sometimes travelled in a convoy with other ships, it is not clear what happened when an itinerary deviated from that specified in the colleganza. Indeed, it is not clear what decision rights any individual travelling merchant had. Over time a system developed in which changes to itinerary were voted on by the merchants on the ship. The ship's captain had no say in this unless safety was an issue. The Maritime Code of 1255 formalized this process. In addition, over time the state took an increasingly active role in organizing the departure times of convoys and later colleganza have legal phrases reflecting this ("By permission of the Doge"). Fourth, the contract specifies a 30-day limit for the settlement of accounts, but does not explain how the accounts were to be kept (double-entry book keeping had not yet been introduced). Over time, an elaborate system for keeping the accounts was developed in which a ship's scribe kept records of all transactions. These were made public and no merchandise was allowed off the ship until all accounts had been settled. Fifth, the contract does not specify how disputes were to be resolved. The Law Merchant was used, but a merchant could refuse this and go instead to civil court or even the Senate, which served as a court of appeals on international trade issues.
} 
return to Venice, Stagnario was welcomed into the ruling elite and his descendants served in the Great Council in nearly every session during the period for which we have records (1261-1295). In the words of Robbert (1999, page 35): "Zaccaria, the grandson of a slave, represented the new man in Venice who climbed to the top because of his business skills." ${ }^{21}$

\section{The Puzzle and a Model}

We have described a virtuous circle: Long-distance trade created a constituency that supported improvements in property-right and contracting institutions and these institutions supported the further growth of trade. We should therefore predict that Venice would continue to grow, as indeed it did. However, the fourteenth century witnessed a marked decline in institutional dynamism, as well as in economic, political and social mobility. In the years 1297-1323 the Serrata created a closed nobility and in the decade after 1323 this nobility put a stranglehold on the most lucrative lines of long-distance trade. The effects of barriers to entry into economic and political markets were significant: "Never again was Venice so largely a maritime nation as it had been in the thirteenth century" (Lane, 1973, p. 170).

How did this happen? Why did the virtuous circle end? International trade, via its impacts on income distribution, created a spectacularly rich subset of merchants who no longer supported financial development. These rich merchants were able to self-finance their long-distance trade and so no longer needed contracting institutions to mobilize capital. In fact, they opposed such institutions (as in Rajan and Zingales, 2003): deep capital markets made entry into long-distance trade easier, which created competition and reduced incumbents' profits. Further, those who recently became rich from long-distance trade then entered politics where they competed for the limited number of valuable political offices ('nobility rents'). Hence incumbents wanted barriers to entry into political markets. In short, increasingly powerful interests opposed institutional dynamism.

To understand the events both of 1297-1323 and the subsequent decade - and their long-term consequences for institutional dynamism in Venice - we develop a model which highlights how wealth dynamics interact with politics to drive institutional change. We build on Banerjee and Newman (1993) in which initial wealth limits the occupational opportunities available to creditconstrained individuals and this in turn affects wealth dynamics. We tailor the occupation and investment opportunities to our Venetian setting and add in coercive political economy considerations.

Venice has a continuum population of constant measure 1. Each person inherits wealth as a bequest from his parent. He is also endowed with one unit of labour from which he earns additional income. Time is continuous, individuals reach the age of maturity at a rate $\lambda$, and when maturity is reached the following sequence of events occurs instantaneously.

\footnotetext{
${ }^{21}$ We find multiple references to Zaccaria Stagnario and his family in original commercial contracts of the period. The above paragraph is based on documents 49, 72, 290, 415, 444, 478 and 479 in the collection edited by Morozzo della Rocca and Lombardo (1940) and on the original documents from the Archivio di Stato di Venezia with catalog numbers UD81001346 and UD02000581. The salary of the Duke of Crete in 1224 was 350 hyperpera (Robbert, 1994, table 7).
} 
1. Mature citizens with inherited wealth above $w_{N}$ become members of the Great Council. In the Council they vote on two issues (votes are decided by simple majority):

(a) Whether membership in the Great Council is hereditary i.e., passed on from father to son.

(b) Whether commoners can invest in international trade. ('Commoners' are citizens with inherited wealth less than $w_{N}$.)

2. Mature citizens who are unhappy with the Great Council's decisions choose whether to revolt. Great Council members and their supporters choose whether to fight the revolt.

3. Mature citizens choose one of four occupations (detailed below), which determines how they invest their labour and capital. They then realize investment outcomes.

4. If Great Council membership is hereditary (the vote in 1a above) and if a mature citizen's wealth exceeds $w_{N}$ after investment outcomes are realized, then the citizen enters the Great Council.

5. Members of the Great Council enjoy a non-pecuniary benefit that accrues to Great Council members. This benefit corresponds to the 'nobility rents' of section $\mathrm{C}$ above.

6. Each mature citizen consumes, dies, and leaves a bequest to his only child.

There is a single physical good in the economy that may be consumed or used as capital. All people are risk neutral and have identical preferences:

$$
U=\left(\frac{c}{1-\gamma}\right)^{(1-\gamma)}\left(\frac{b}{\gamma}\right)^{\gamma}-l+g-d
$$

where $c$ is the individual's consumption, $b$ is the bequest to his offspring, $l$ is the labour effort he exerts and $g$ is the rents from Great Council membership. For non-members, $g=0$. For members, $g$ is positive and decreasing in the number of Council members.

Turning to $d$ in equation ( 1 ), citizens whose interests are harmed by Great Council votes may choose to revolt. $d$ in the utility function captures the ex post cost of a revolt: $d=0$ if there is no revolt or if there is a revolt and the individual is on the winning side. $d>0$ if there is a revolt and the individual is on the losing side. We assume that $d$ is so large that no one participates in a revolt they cannot win (the individual is hanged in St. Mark's square). Details of the revolt 'technology' appear below.

Turning to occupations, a Venetian's capital and labour may be employed in one of four occupations:

- Craftsman: He uses his labour effort to produce $v$ units of output, where $v>1$ is fixed by technology.

- Travelling merchant: He signs a colleganza contract with a sedentary merchant. The sedentary merchant puts up the capital; the travelling merchant contribute his labour (effort) but needs to be monitored. The voyage yields a high rate of return $\rho_{1}$ with probability $\sigma$ and a low rate of return $\rho_{0}>0$ with probability $1-\sigma$. The expected rate of return is $\bar{\rho}=\sigma \rho_{1}+(1-\sigma) \rho_{0}$. The travelling merchant receives an endogenous share of profits. 
- Self-financed merchant: He makes a fixed indivisible investment $I$ and uses his labour effort on a ship to foreign ports. The voyage yields a high rate of return $\rho_{1}^{\prime}$ with probability $\sigma$ and a low rate of return $\rho_{0}^{\prime}>0$ with probability $1-\sigma$. The expected rate of return is $\bar{\rho}^{\prime}=$ $\sigma \rho_{1}^{\prime}+(1-\sigma) \rho_{0}^{\prime}$.

- Sedentary merchant: He makes a fixed indivisible investment $\mu I$ and uses his labour effort to monitor $\mu$ travelling merchants. Monitoring is an indivisible activity and one cannot monitor another monitor, so that as in Banerjee and Newman (1993), $\mu>1$ is an exogenously given constant. Returns are assumed to be perfectly correlated across a sedentary merchant's $\mu$ colleganzas, and he receives an endogenous share of profits.

There is also a safe divisible asset that yields a fixed rate of return $r$, where $0<r<1 / \gamma-1$ and $\gamma$ is defined in equation (1). ${ }^{22}$ We also assume $\bar{\rho}>r$ and $\bar{\rho}^{\prime}>r$ so that investing in colleganza is always preferred to investing in a safe asset.

Following Banerjee and Newman (1993), we assume that, due to capital market imperfections, people can borrow only limited amounts. As a result, occupations that require high levels of investment are beyond the reach of individuals with lower wealth levels. ${ }^{23}$

Let $w_{M}=I$ ( $M$ for middle wealth) denote the minimum wealth level required to become a self-financed merchant and $w_{H}=\mu I$ ( $H$ for high wealth) denote the minimum wealth level required to become a sedentary merchant. To capture the historical evidence, we assume that being a sedentary merchant opens the doors to participation in the Great Council. That is, $w_{H}=w_{N}$. (See point 4 above.) Let $P_{L}$ be the share of the population with wealth $w<w_{M}$, let $P_{M}$ be the share with $w_{M} \leqslant w<w_{H}$, and let $P_{H}$ be the share with $w \geqslant w_{H}$. Since wealth $w$ evolves endogenously, the Ps evolve endogenously.

As in Banerjee and Newman (1993), this type of model is tractable if one focuses on parameter configurations such that children's occupational choices depend on the occupation of their parents and on the success or failure of their projects, but not on the parents' specific wealth level. Rather than analyzing every possibility, we focus on a case that captures key elements of the evolution of international trade and political institutions in Venice.

Consider the market for travelling merchants. Suppose there are very few high-wealth people (all of them are sedentary merchants). Then very few travelling merchants are needed and the returns to being a travelling merchant are low — so low that they are no better off than craftsmen. This implies that the travelling merchant's profit share is: ${ }^{24}$

$$
\underline{\alpha}=\frac{v}{\bar{\rho} I} .
$$

\footnotetext{
${ }^{22} r<1 / \gamma-1$ ensures that if someone invests all his wealth in the safe asset and gets no labour income, then his offspring will be poorer than him: $\gamma(r+1) w<w$ or $r<1 / \gamma-1$.

${ }^{23}$ More specifically, the ability of a borrower to default on a loan, subject to a fixed non-monetary punishment if caught, leads to credit rationing. As in Ghatak and Jiang (2002), we let the probability of being caught be zero so that only those with enough wealth can invest. (If we let the probability of being caught be strictly positive, all wealth thresholds described below are simply raised by a constant).

${ }^{24}$ An individual with inherited wealth $w<w_{M}=I$ ends up with wealth $v+(r+1) w$ if he chooses to become a craftsman and with expected wealth $\alpha \bar{\rho} I+(r+1) w$ if he chooses to become a travelling merchant. Equating the two yields $\underline{\alpha}$. (Recall that $\bar{\rho}$ is the expected return on investment $I$ and $\underline{\alpha}$ is the travelling merchant's share of colleganza profits, so that $\alpha \bar{\rho} I$ is a travelling merchant's expected income from a colleganza.)
} 
If there are many high-wealth people (all of them are sedentary merchants) then they will demand so many travelling merchants that there will be no more craftsmen. At this point the returns to being a travelling merchant rise, which squeezes the profits of sedentary merchants. In equilibrium, high-wealth people $\left(w>w_{H}\right)$ are so squeezed that they are indifferent between being sedentary merchants and self-financed merchants. This implies the following profit share for travelling merchants: ${ }^{25}$

$$
\bar{\alpha}=\frac{\mu(\bar{\rho}-r)-\left(\bar{\rho}^{\prime}-r\right)}{\mu \bar{\rho}} .
$$

Recalling that there are $P_{H}$ sedentary merchants, each hiring $\mu$ travelling merchants, equation (2) applies when there are relatively few high-wealth people $\left(\mu P_{H} \leq P_{L}\right)$ and equation (3) applies when there are relatively many high-wealth people $\left(\mu P_{H}>P_{L}\right){ }^{26}$

\section{A Few Rich Merchants $\left(\mu P_{H} \leq P_{L}\right)$}

Panel (a) in figure 3 presents wealth dynamics when the demand for travelling merchants is low $\left(\mu P_{H}<P_{L}\right)$. It plots the size of an individual's bequest $b$ against his initial (inherited) wealth level $w$. The size of a bequest depends on the individual's choice of occupation and the success or failure of his projects. In every case, the bequest is simply a share $\gamma$ of the wealth of the individual at the end of his life. The choice of occupation in our credit-constrained economy depends on initial wealth: sedentary merchants require wealth $w \geq w_{H}$; self-financed merchants require wealth $w \geq$ $w_{M}$; while travelling merchants and craftsmen do not require any wealth.

Consider first the three upward-sloping lines to the left of $w=w_{M}$. A low-wealth individual who inherits $w<w_{M}$ can choose between being a craftsman and being a travelling merchant. If working as a craftsman, his labour income is $v$ (middle line). If working as a travelling merchant, his labour income is $\underline{\alpha} \rho_{1} I$ with probability $\sigma$ (top line) and $\alpha \rho_{0} I$ with probability $1-\sigma$ (bottom line). Whether a craftsman or a travelling merchant, he also earns non-labour income $r w$ from placing his inherited wealth in the safe asset. Note that $\gamma(r+1)$ is the slope of all three lines, which reflects the fact that those with higher initial wealth $w$ end up with higher non-labour income $r w$. In panel (a), $\underline{\alpha}$ adjusts to keep an individual indifferent between being a craftsman and a travelling merchant. As drawn in the region $w<w_{M}$, initial wealth $w$ is not enough for the child to become a self-financed merchant (i.e., $b<w_{M}$ ). This will be what matters for the wealth dynamics of the poor.

\footnotetext{
${ }^{25}$ Consider an individual with inherited wealth $w>w_{H}=\mu I$. If he chooses to become a self-financed merchant he expects to end up with wealth $\left[\bar{\rho}^{\prime}+1\right] I+(r+1)(w-I)$. If he chooses to become a sedentary merchant he expects to end up with wealth $[(1-\bar{\alpha}) \bar{\rho}+1] \mu I+(r+1)(w-\mu I)$, where $(1-\bar{\alpha}) \bar{\rho} \mu I$ is his expected profits after payments to travelling merchants, $\mu I$ is the capital invested in colleganza, and $(r+1)(w-\mu I)$ is the wealth invested in the safe asset plus returns on this. Equating the expected returns to self-financed and sedentary merchants yields $\bar{\alpha}$.

${ }^{26} \mathrm{~A}$ reader whose knowledge of colleganze is from secondary sources may think that profit shares are fixed at $1 / 4$. This is not the case: we observe many colleganza with alternative profit shares. Venetian law was explicit that profit shares need not be 1/4. In the Gli Statuti (Besta and Predelli, 1901) in the chapter (16) on Observing Contracts we have "We decree also concerning contracts that it ought to be observed that he who receives money from anyone, so that he may make a profit with it, disregards nothing in the contract, but profiting with the received money up to the time stated, holds for himself from the success the fourth part or as much as is contained in the contract. Moreover, in the accustomed manner he simultaneously ought to give to the creditor the remaining parts with the capital." (Authors' translation, italics added.)
} 

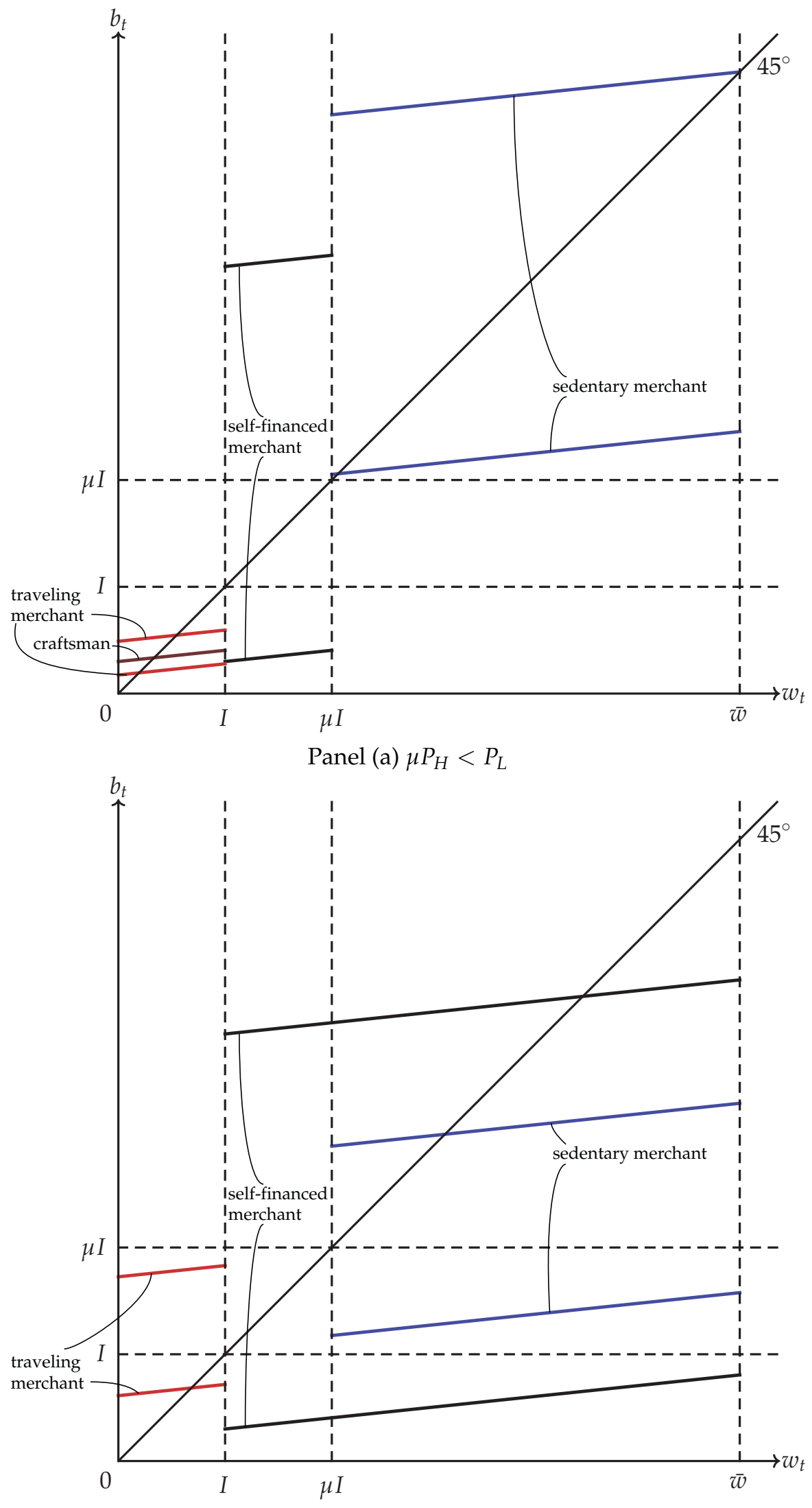

Panel (b) $\mu P_{H} \geqslant P_{L}$

Figure 3: Occupations and Bequests by Individual Wealth 
Staying with panel (a), consider an individual in the middle-wealth region $w_{M} \leqslant w<w_{H}$. He is wealthy enough to be a self-financed merchant $\left(w_{M} \leqslant w\right)$, but not a sedentary merchant $\left(w<w_{H}\right)$. Further, expected returns are higher for self-financed merchants than for craftsmen or travelling merchant. Hence he chooses to be a self-financed merchant. He thus makes a fixed indivisible investment $I$ and the voyage yields profit $\rho_{1}^{\prime} I$ if successful (probability $\sigma$ ) and profit $\rho_{0}^{\prime} I$ if unsuccessful. He also receives a return $r(w-I)$ from placing his remaining wealth in the safe asset. The involvement in international trade of middle-wealth individuals creates mobility in the wealth distribution: a successful self-financed merchant bequests $b>w_{H}$ and so his offspring begins life as a high-wealth individual, while an unsuccessful self-financed merchant bequests $b<w_{M}$ and so his offspring begins life as a low-wealth individual.

Looking finally at high-wealth individuals, someone with inherited wealth $w \geqslant w_{H}$ always becomes a sedentary merchant (it gives higher expected returns than any other occupation). He makes a fixed indivisible investment $\mu I$ in colleganzas. His profit net of payments to travelling merchants is $(1-\underline{\alpha}) \rho_{1} \mu I$ if successful and $(1-\underline{\alpha}) \rho_{0} \mu I$ if unsuccessful. He also receives a return $r(w-\mu I)$ from placing his remaining wealth in the safe asset. When there are relatively few high-wealth individuals and relatively many low-wealth individuals, the returns for a sedentary merchant are always high enough that he bequests $b>w_{H}$ and his child also begins life with high wealth.

Stepping back from the details of panel (a), all wealth mobility comes from middle-wealth individuals. Depending on their success as self-financed merchants, their children are either upwardly mobile (with probability $\sigma$ ) or downwardly mobile (with probability $1-\sigma$ ). The children of all others (low- and high-wealth) remain in the same wealth groups as their parents. This immediately implies the following dynamics:

$$
\left(\begin{array}{c}
\dot{P}_{L} \\
\dot{P}_{M} \\
\dot{P}_{H}
\end{array}\right)=\lambda\left(\begin{array}{ccc}
0 & (1-\sigma) & 0 \\
0 & -1 & 0 \\
0 & \sigma & 0
\end{array}\right)\left(\begin{array}{c}
P_{L} \\
P_{M} \\
P_{H}
\end{array}\right), \text { if } \mu P_{H} \leqslant P_{L}
$$

where a dot indicates a time derivative. (Recall that $\lambda$ is the share of the population that is active.)

\section{B Many Rich Merchants $\left(\mu P_{H}>P_{L}\right)$}

Panel (b) presents the case where the relative number of high-wealth individuals increases sufficiently $\left(\mu P_{H}>P_{L}\right)$ that the returns to travelling merchants are given by equation (3) instead of equation (2). Low-wealth individuals now all become travelling merchants and, if successful, bequest to their children $b>w_{M}$, so that these begin mature life as middle-wealth individuals. For middle-wealth individuals, nothing changes. For, high-wealth individuals, there is now indifference between being self-financed or sedentary. The children of successful high-wealth individuals inherit high wealth. The children of unsuccessful high-wealth individuals inherit middle wealth if their parents were sedentary merchants and low wealth if their parents were 
self-financed merchants. This implies the following dynamics: ${ }^{27}$

$$
\left(\begin{array}{c}
\dot{P}_{L} \\
\dot{P}_{M} \\
\dot{P}_{H}
\end{array}\right)=\lambda\left(\begin{array}{ccc}
-\left(\sigma+\frac{1-\sigma}{\mu}\right) & (1-\sigma) & (1-\sigma) \\
\left(\sigma+\frac{1-\sigma}{\mu}\right) & -1 & 0 \\
0 & \sigma & -(1-\sigma)
\end{array}\right)\left(\begin{array}{c}
P_{L} \\
P_{M} \\
P_{H}
\end{array}\right), \text { if } \mu P_{H}>P_{L}
$$

Since total population is fixed, we can express the above dynamics of equations (4) and (5) in terms of $P_{L}$ and $P_{H}$ only, with $P_{M}=1-P_{L}-P_{H}$ :

$$
\begin{aligned}
\dot{P}_{L} & = \begin{cases}\lambda(1-\sigma)\left(1-P_{L}-P_{H}\right) & \text { if } \mu P_{H} \leqslant P_{L}, \\
\lambda(1-\sigma)-\lambda\left(1+\frac{1-\sigma}{\mu}\right) P_{L} & \text { if } \mu P_{H}>P_{L}\end{cases} \\
\dot{P}_{H} & = \begin{cases}\lambda \sigma\left(1-P_{L}-P_{H}\right) & \text { if } \mu P_{H} \leqslant P_{L} \\
\lambda \sigma-\lambda \sigma P_{L}-\lambda P_{H} & \text { if } \mu P_{H}>P_{L} .\end{cases}
\end{aligned}
$$

Figure 4 represents on a simplex the evolution of Venice's wealth distribution as given by these differential equations. $P_{L}$ is measured along the horizontal axis, $P_{H}$ is measured along the vertical axis, and $P_{M}=1-P_{L}-P_{H}$. Assume an initial wealth distribution with a mixture of low- and middle-wealth individuals, but very few high wealth individuals, which corresponds to a point like $A$ on the simplex and characterizes Venice in its early days. Over time, success as self-financed merchants will allow some middle-wealth individuals and their children to join the high-wealth group, while failure makes others join the low-wealth group. This makes the wealth distribution move upwards and rightwards on the simplex towards point $B$. When the wealth distribution crosses the $P_{L}=\mu P_{H}$ line at point $B$, all low-wealth individuals are now working as travelling merchants. Any further increase in high-wealth individuals $\left(P_{H}\right)$ creates competition among them for travelling merchants, which bids up $\alpha$ from $\underline{\alpha}$ to $\bar{\alpha}$. This increases wealth churning: the poor are now more upwardly mobile and the rich are now more downwardly mobile. As a result, the economy moves towards the steady state at $C$. The high degree of intergenerational mobility and churning that characterizes this steady state was preempted, as we shall see, by political developments.

\section{Politics}

Recall that membership in the Great Council generates rents for each member ( $g$ in the equation 1 utility function) and that these per capita rents are decreasing in the size of the Great Council. Those who are born with inherited wealth $w>w_{M}$ and hence immediately become Great Council

\footnotetext{
27The explanation is as follows. Consider the first row, which deals with the change in the measure of low-wealth people. This can be written as $\dot{P}_{L}=\lambda\left[-\sigma P_{L}+(1-\sigma) P_{M}+(1-\sigma)\left(P_{H}-\frac{1}{\mu} P_{L}\right)\right]$. Among those who initially have low wealth, a fraction $\sigma$ are successful as travelling merchants and so their children will start life as middle-wealth individuals. This accounts for the term $-\sigma P_{L}$. Among those who initially have middle wealth, a fraction $(1-\sigma)$ are unsuccessful as self-financed merchants and so their children start life as low-wealth people. This accounts for the term $(1-\sigma) P_{M}$. Among those who initially have high wealth, there is one sedentary merchant for every $\mu$ travelling merchants i.e., there are $\frac{1}{\mu} P_{L}$ sedentary merchants. The rest, $P_{H}-\frac{1}{\mu} P_{L}$, are self-financed merchants. A fraction $(1-\sigma)$ of these are unsuccessful and their children begin life as low-wealth people. This accounts for the term $(1-\sigma)\left(P_{H}-\frac{1}{\mu} P_{L}\right)$. Finally, individuals mature at a rate $\lambda$ and the dynamics apply only to them.
} 


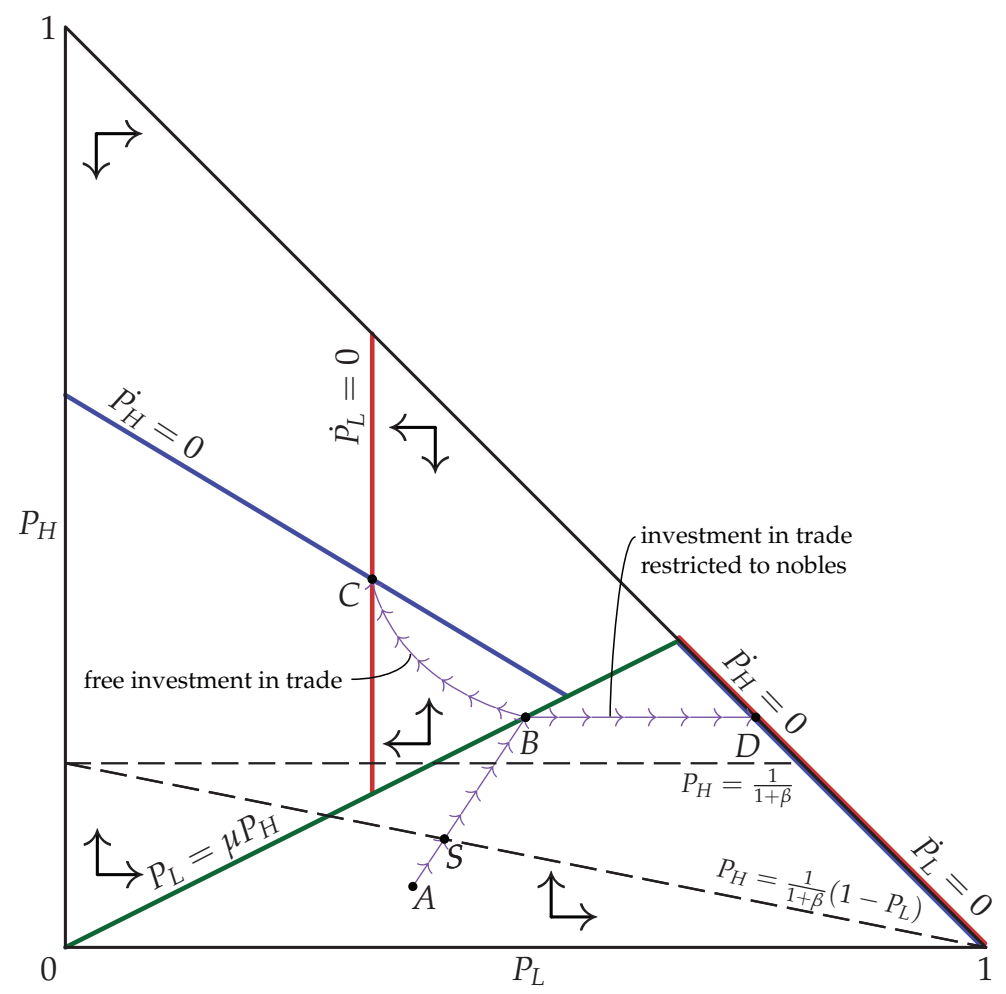

Figure 4: Evolution of the Wealth Distribution

members and would like to prevent further entry into the Council. On the other hand, those who are born with wealth $w_{L}<w<w_{M}$ and have a chance of entering the Great Council later in life want Great Council membership to remain open. This sets up a political conflict.

As described in point 1a above, the Great Council votes on whether membership should become hereditary or remain open to newcomers. These new members would be drawn from those who initially have middle wealth and thus can potentially attain wealth $w>w_{M}$ through commercial success. Thus, if entry of newcomers were restricted, middle-wealth individuals would have a reason to revolt.

For simplicity, we assume that the outcome of a revolt depends deterministically on the relative strengths of the two sides and the revolt succeeds if and only if the strength of those revolting is strictly greater than the strength of those supporting the Great Council. The strength of those supporting the revolt is given by their population share, which in this case is $P_{M}$. The strength of those supporting the Great Council vote is given by their population share $P_{N}$ times a factor $\beta>1$. $\beta$ captures the ability of those in power to mobilize the state's coercive capacity. (The empirical counterpart to $\beta$ is described below.) Thus, a revolt against the political closure of the Great Council succeeds whenever $\beta P_{H}<P_{M}$, or, since $P_{M}=1-P_{L}-P_{H}$, whenever

$$
P_{H}<\frac{1}{1+\beta}\left(1-P_{L}\right)
$$

If this condition is not met then a revolt is defeated and its participants are hanged in Saint Mark's Square. 
Figure 4 illustrates the timing of closure i.e., the timing of the Serrata. As society moves from point $A$ to point $B$ it crosses the line $P_{H}=\frac{1}{1+\beta}\left(1-P_{L}\right)$ at point $S$. ( $S$ stands for Serrata.) Before this point, if members of the Great Council had voted for the Serrata they would have faced a successful revolt. After point $S$, members of the Great Council are powerful enough as a group to vote for hereditary membership without facing a revolt. From that point on, a person becomes a member of the Great Council only if his father was a member: Membership, which until then had been associated with commercial wealth, becomes hereditary. A formal nobility is established and equated with membership in the Great Council.

After the Great Council becomes hereditary, many non-members continue to accumulate high wealth through commercial success. As they do so, these commoners become sedentary merchants and compete economically with nobles i.e., with Great Council members, all of whom are sedentary merchants. This competition squeezes the profits of nobles and, in particular, at point $B$ the expected profits of sedentary merchants drop discretely. ${ }^{28}$ Nobles have a strong incentive to exclude commoners from international trade just before this happens. This corresponds to the second of the two Great Council votes. (See point $1 \mathrm{~b}$ above.) Thus, at point $B$, Great Council members will vote in favour of excluding commoners from international trade if doing so does not trigger a revolt.

Excluding commoners from international trade harms a larger segment of Venetian society than did excluding commoners from the Great Council. It forces all commoners to be craftsmen, which at point $B$ makes all commoners worse off. At the time of the Serrata, the noble population share was frozen at $P_{N}^{S}=\frac{1}{1+\beta}\left(1-P_{L}^{S}\right)$ where $P_{L}^{S}$ is $P_{L}$ valued at point $S$. Rearranging this implies that the power of nobles, $\beta P_{N}^{S}=1-P_{N}^{S}-P_{L}^{S}$, is less than the power of commoners $\left(1-P_{N}^{S}\right)$. Thus, any attempt by nobles to restrict investment in trade would be defeated by a commoner revolt. To succeed, nobles need to co-opt some of the nouveau riche commoners who had recently gained high wealth through commercial success but had been excluded from the Great Council. They can do this by increasing membership in the Great Council to $P_{N}=\frac{1}{1+\beta} \cdot{ }^{29}$ As we shall see, this event is referred to in Venetian history as the 'Enlargement of the Great Council.' With this influx of new members, the Great Council is tremendously powerful: membership defines nobility status and commoners are excluded from the highly lucrative long-distance trade.

Returning to figure 4 , the wealth distribution now moves rightwards from point $B$ to point $D$. Despite the political and economic closure, Venice continues to engage in international trade. However, compared with the evolution towards $C$ that Venice would have followed absent any restrictions, a smaller fraction of Venice's population is involved in international trade, its wealth distribution is more polarized, and social and economic mobility is reduced to a minimum. It is time to document this in the historical record.

\footnotetext{
${ }^{28}$ There are many ways of modelling the drop in profits. Here it is caused by competition for inputs (travelling merchants) which drives up costs. Alternatively, it could have been modelled as reduced revenue from greater competition in product markets.

${ }^{29}$ Rearranging, this becomes $\beta P_{N}=1-P_{N}$, which means that commoner strength $1-P_{N}$ does not exceed noble strength $\beta P_{N}$ and the Great Council can put down the revolt.
} 


\section{The Oligarchs Triumphant}

In this section we review three key events in Venetian history through the lens of our model. First, we provide new evidence from the period 1261-1295 that mobility into and out of the Great Council was eroding the power of many established families. Second, we argue that this erosion is essential for understanding the Serrata of 1297-1323, the most important constitutional event in Venetian history. Norwich (1977, page 181) describes the Serrata as "The Oligarchs Triumphant." Third, we show that towards the end of this period and culminating in the early 1330s, a series of laws were passed that severely restricted the ability of non-nobles to engage in long-distance trade. Further, among nobles, it was the most powerful nobles who benefited most from these restrictions.

\section{A The Changing Membership of the Great Council}

We start with novel evidence that in the period leading up to the Serrata: (1) there was a high degree of mobility into and out of the Great Council; (2) a majority of seats in the Great Council were held by a relatively small number of powerful families; and, (3) some of these families were losing seat shares to merchants that had not previously participated in the Great Council. To this end, we have constructed a unique database on representation in the Great Council. The Council recorded the names of its members and these lists have survived for each of the years 1261, 1264-70, 1275-83, and $1293-95 .^{30}$ A Great Council session lasted for one year, starting in October. Thus, for example, the 1295 session ends in October 1296. The handwritten lists, together with other surviving records of Great Council deliberations, have been transcribed in the Deliberazioni del Maggior Consiglio di Venezia (Cessi, 1931-1950).

The lists are complex. They contain 8,218 names and our analysis is based on the 8,103 names that are legible. As is well known, Venetian society in general and Great Council elections in particular were organized along family (i.e., clan) lines. See, for example, Raines (2004). It is therefore important to group individuals' names into families. Most family names have multiple variants and standardizing these was a lengthy and meticulous process. ${ }^{31}$

Figure 5 graphically portrays the extent of mobility into and out of the Great Council and the erosion of seat shares of families who were initially represented in the Great Council. Consider the dashed line. To construct it, we first rank all families based on their initial seat shares i.e., on the average number of seats the family held during the first three available sessions (1261, and 1264-1265). For example, the Contarini family ( 1 on the horizontal axis) held the most seats, $4.4 \%$

\footnotetext{
$3^{30}$ There are very partial membership lists for 1284 and 1296 . No other years of data are available.

${ }^{31}$ There are many difficulties. The same family name appears sometimes in Latin and other times in Italian (e.g., Mauroceno or Morosini). There are multiple patronymic prefixes ( $\mathrm{d}^{\prime}, \mathrm{da}$, de, di, dalla, della, de ca', de cha, de Casa, da Casa). There are also many spelling variants (up to 12 in the case of the Susenullo family), the doubling of the ' $n$ ' or of the ' 1 ' being the most common variants. Other variations reflect differences between Venetian and Italian, such as the alternative spellings ' $\mathrm{c}^{\prime}, \mathrm{z}^{\mathrm{z}} \mathrm{\text {'or }}$ ' $\mathrm{zh}$ ' for the interdental voiceless fricative (a sound that is used in Venetian but not in Italian). In the lists,an elected member is sometimes represented by a proxy (ad vocem). In this case we record the name of the elected member because as Mozzato (2004) shows, proxies faithfully represented their elected members. The standardization was done with the careful assistance from Lisa Chen and Jennifer Konieczny. They are Ph.D. students in the Medieval History Department at the University of Toronto. Lisa Chen specializes in Venetian literary texts. Jennifer Konieczny specializes in Florentine legal texts.
} 


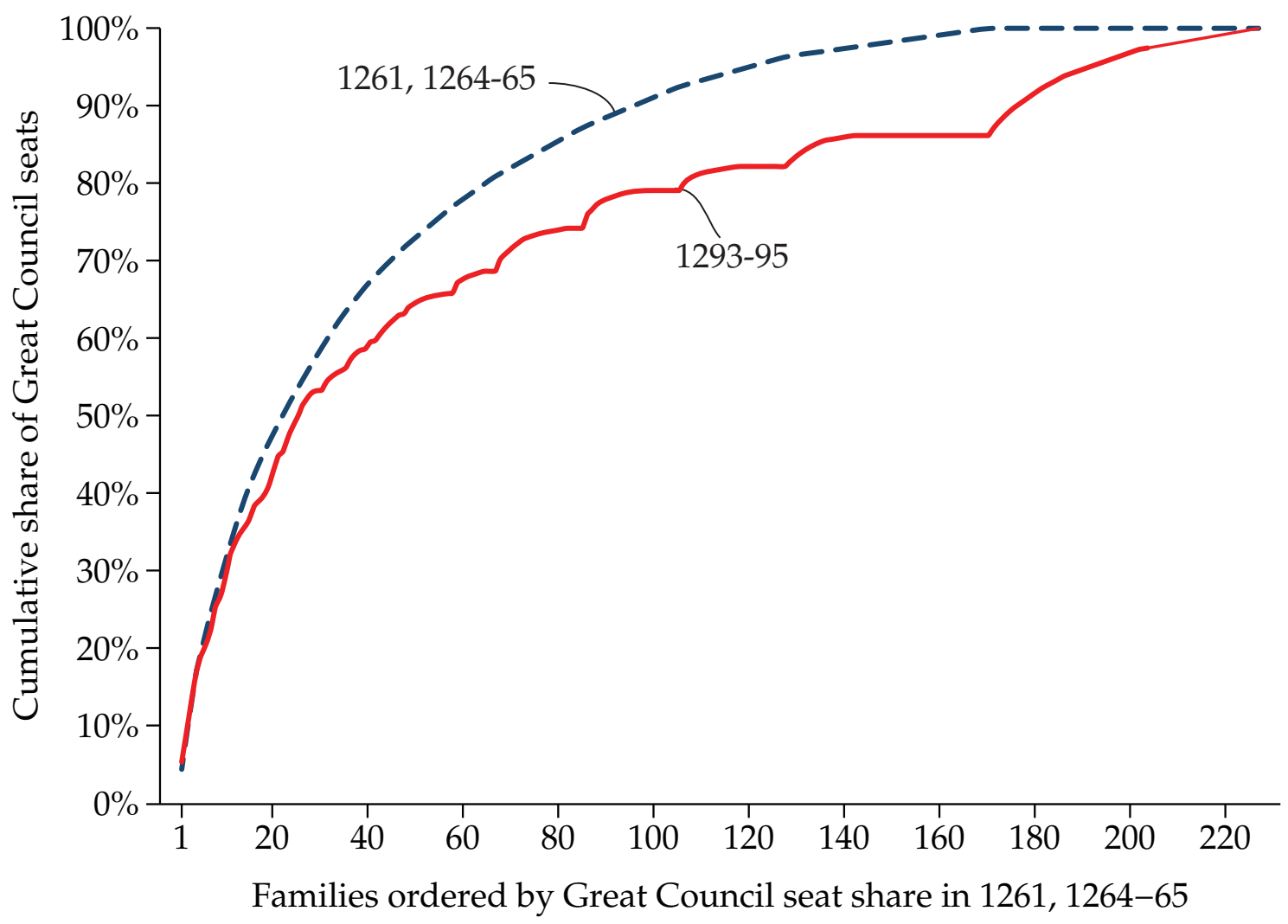

Figure 5: Share of Great Council Seats Held by Families Dating to 1261, 1264-1265

of the total. This $4.4 \%$ appears on the vertical axis. The Dandolo family ( 2 on the horizontal axis) held the same share of seats $(4.4 \%)$ so that the cumulative seat shares held by these two families was $8.8 \%$. This $8.8 \%$ is displayed on the vertical axis. Moving rightward along the solid line, $30 \%$ of the seats were held by 10 families, $50 \%$ of the seats were held by 22 families and $100 \%$ of the seats were held by 168 families. This gives meat and precision to a common observation in the literature that among Venetian families, "between 20 and 50 might be considered great families" (Lane, 1973, page 100).

The solid line in figure 5 presents the cumulative seat shares at the end of our sample, during the last three available sessions (1293-1295). We retain the ordering of names from 1261 and 1264-1265 so that 1 is still Contarini, 2 is still Dandolo, etc. Families that did not appear in this initial period are ranked by seat shares in the 1293-1295 period. (This is the concave section at the right end of the solid line.) Three features of figure 5 stand out.

First, at the point where the dashed line reaches $100 \%$, the solid line only reaches $86 \%$. Thus, $14 \%$ of the end-period seats were held by families that entered the Great Council after the initial period. There were 56 new families. Thus, there was considerable mobility into the Council. This was not simply entry of a bunch of small-time players. The seat shares of new families were highly skewed, as can be seen from the concavity of the final portion of the solid line. The lion's share of the $14 \%$ (about a third of it) was captured by just 5 of the 56 new families. For example, the new 
family with the most seats was the Caroso family who went from no seats to being $31^{\text {st }}$ in the seatshare rank of the end period. This rank would place them among Lane's great families. Further, most of the new families were engaged in long-distance trade, as evidenced by their appearance in commercial contracts. For example, the new family with the second-most seats was the Cavatorta, who the surviving records show settling accounts with Zaccaria Staniario for trade between Venice and Constantinople. ${ }^{32}$ Thus, these new families were quickly growing wealthy and politically powerful from long-distance trade.

The second feature of the figure is mobility out of the Council. The flat portions of the solid line are due to families who initially had seats, but ended up with none. There are 53 such families among the initial 168. This implies that the exit rate from the Great Council was 1.3\% per year. This was ten times higher than the exit rate after the Serrata. 33 For example, in the initial period the Dauro family held $1.1 \%$ of the seats and was ranked $26^{\text {th }}$, yet the family was no longer in the Great Council by the end period.

The third and most striking feature of the figure is that the solid line (1293-1295) is well below the dashed line (1261 and 1264-1265). Established families - even some of the most powerful were losing seat shares. For example, the Falier family, one of the founding families of Venice who had given the commune two Doges, held $2.5 \%$ of the seats and was ranked $6^{\text {th }}$ in the initial period but by the end period its rank had dropped to $18^{\text {th }}$. Similarly, the powerful Zane family saw their seat rank drop from $9^{\text {th }}$ to $26^{\text {th }}$. The Falier's and Zane's were lucky: their slide into obscurity was halted by the Serrata.

In summary, figure 5 shows that there was a high degree of mobility into and out of the Great Council, that new members were engaged in long-distance trade, and that the power of many great families was being eroded by up-and-coming families.

\section{B The Serrata, the 'Enlargement of the Great Council,' and State Capacity for Repression}

Wealthy families did not take this mobility lying down. Their attack began in the Great Council where they introduced a series of motions aimed at gaining permanent control of the Council. After the failure of four such motions during 1286-1296, a landmark vote on February 29, 1297 effectively handed control of Great Council elections to a small number of powerful families. ${ }^{34}$ In particular, control over elections passed onto the hands of the Council of Forty, a government organ "which had never before claimed a leading role in the state" (Rösch, 2000, page 74) and whose elite membership was top-heavy with older, powerful families. Further, the 1297 vote made it much easier to be re-elected if one had recently served on the Great Council and much harder to be

\footnotetext{
${ }^{32}$ The settlement is in document \#75 in Lombardo and Morozzo della Rocca, 1953. The new family with the third-most seats was the Nicola, who were investors in the colleganza of document \#811 in Morozzo della Rocca and Lombardo (1940). The new family with the fourth-most seats was the Barastro, who appear in the colleganza of documents \#749, \#751, \#794, and \#834 in Morozzo della Rocca and Lombardo (1940).

33See below. The calculation is $168(1-\gamma)^{(1293-1265)}=168-53$ which implies an annual exit rate $\gamma=1.3 \%$. Of the 172 families with seats in 1293-1295 only 20 exited the Great Council between the 1323 and 1410 which implies an exit rate after the Serrata of $0.13 \%$.

34The relevant motions are in Cessi (1931-1950, volume 1), page $156 \#_{118}$ (October 3, 1286), pages 156-157, \#120 (October 5, 1286), page 157, \#123 (October 17, 1286) and page 396 \#6 (March 6, 1296), and in Cessi (1931-1950, volume 3), pages 417-418 \#104 ('The Last Day' of February, 1297). Translations are available from the authors on request.
} 
elected if one had never served before. Votes in 1298, 1300 and 1307 substantially strengthened this asymmetry between insiders and outsiders. Membership in the Great Council had taken a major step towards being 'locked in.' See Hazlitt (1966), Lane (1971, 1973) and Rösch (2000). 35

Political closure was tightened with a series of laws that created a Venetian nobility. The first of these, dating from 1310, states that a nobiles was a man 'who was or could be a member of the [Great] Council' (Ruggiero, 1980, page 9). In 1315, an official registry of the nobility was created, which quickly evolved into the Libro d'Oro. The last of the Serrata laws was passed in 1323. It unequivocally made membership in the Great Council a hereditary position. Men whose fathers and grandfathers had been in the Great Council automatically became members at age 25 .

Those excluded from the nobility did not give up without a fight. In fact, the period 1300-1355 was to be the most internally violent period in Venetian history from 976 to the demise the the Serene Republic in 1797. In early 1300, a popular commoner named Boccono along with 11 of his associates forced their way into the Great Council chambers. Boccono appears to have been intent on murdering several Council members and brow-beating the remainder into re-enfranchising those excluded by the Serrata. Arms were not permitted in the chambers so Boccono and his associates represented a real threat, all the more so because they were backed by a crowd of armed supporters waiting outside in St. Mark's Square. By a stroke of luck, an overheard conversation at church revealed the plot: the 12 conspirators were disarmed in the Council chambers and executed that night. Their bodies were left hanging in St. Mark's Square where they served as a warning. In addition, 40 other supporters of the conspiracy were exiled and had their properties confiscated. See Ruggiero (1980, chapter 1).

Discontent continued to percolate over the next decade as additional laws made it clear just how exclusive the Serrata was becoming. Discontent boiled over on the night of June 15, 1310 when Venice was rocked by an armed insurrection of frustrated outsiders who increasingly feared that their exclusion from the Great Council was permanent. By luck, the plot was revealed the night before by a defector, and even this may not have prevented the insurrection: a violent storm wreaked havoc with communications between the two groups of insurgents who were converging on St. Mark's Square and the mis-coordinated attack was repulsed. A successful revolt was barely averted. See Hazlitt (1966, pages 541-542). ${ }^{36}$

A sense of panic began to grip the elite: they might not be so lucky next time. It was time for a new, two-pronged approach that involved co-opting the most powerful of the discontented and building the coercive capacity to repress the remainder. In 1310-1311 the elite co-opted its most powerful opponents by inducting them into the Great Council. This one-off event is famous in Venetian history and is known as the 'Enlargement of the Great Council.' The size of the Council, which had been about 450 members, was more than doubled to 1,017 (Romanin, 1854, page 347).

\footnotetext{
${ }^{35}$ Most of these motions cannot be easily summarized; however, clauses governing the election of new members are particularly easy to summarize and illustrate the growing asymmetry. In 1297, a new member required the support of at least 12 of the 40 Council of Forty members. In 1300 it rose to 20 , in 1307 it rose to 25, and in 1311 it rose to 30 . See Rösch (2000, pages 74-75).

${ }^{36}$ Ruggiero (1980, chapter 1) emphasizes that the motivation for both revolts was opposition to the Serrata. Rösch (2000) disagrees, arguing that the revolts were personally motivated. A more likely motivation was inter-clan rivalry (Hazlitt, 1966, chapter xx), a point we will discuss in section 7 below. For our purposes, what matters is the outcome of the Serrata rather than the now-obscure intentions of some of its participants.
} 
This had the expected effect of defusing the most violent expressions of outsider frustration and no similar enlargement was ever necessary again. Interestingly, the diluting effects of the Enlargement were not long-lasting: Raines (2004, page 32) shows that almost all of the Enlargement families had disappeared from the Great Council within a century.

The building of coercive capacity had a more lasting, indeed permanent, effect. The revolt occurred on June 15, 1310. On June 30, the Great Council declared martial law and on July 10 the first meeting of the infamous 'Council of Ten' was convened. The Council of Ten was initially tasked with tracking down the supporters of the revolt, but it evolved into the Venetian state's repressive apparatus. From its beginnings, the Ten's authority within the state hierarchy was left intentionally ambiguous. For example, it was not appointed by the Great Council nor accountable to it. 37 Over time, the Council of Ten arrogated to itself whatever powers it needed. For example, in 1319 it created its own police force. Even this was not enough to quell the uproar over the Serrata for in 1328 the Ten executed the brothers Barozzi for leading a conspiracy against the nobility. By mid-century, the Council of Ten had accumulated the necessary resources and experience to repress internal dissent: the last significant attempt to overthrow the Venetian state by violence came on April 15, 1355 and was uncovered from multiple sources by the Ten (Norwich, 1977, page 227). ${ }^{38}$

What the most powerful members of the Venetian elite had failed to get in 1286, they grabbed in 1323. Co-option (the Enlargement) and coercion (the Council of Ten) were their tools, just as in our model.

\section{The Closure of Long-Distance Trade}

In the decade following 1323, the newly-defined nobility passed a series of laws whose consequence was to limit participation by commoners in the most lucrative aspects of long-distance trade. Two of these were particularly important, the re-organization of the galley trade and wealth-based restrictions on who could trade.

Galleys had always handled the most lucrative traded goods, including cloth, silk, cash, bullion and spices (Lane, 1963, page 181). Their speed allowed them to escape capture by pirates and their small cargo holds made them impractical for anything but valuable light-weight goods. During the second half of the thirteenth century the Commune took a hand in regulating convoys of these privately owned vessels, and this regulation expanded dramatically during the Serrata. 39 Then in 1325 , Venice experimented with a dramatically new organization of the galley trade: instead of convoys of primarily privately owned and operated galleys, Venice moved to a system of

\footnotetext{
37Its membership was secret and drawn exclusively from the most powerful families. As few as twenty families controlled the Council in the fourteenth century (Ruggiero, 1980, page 16).

${ }^{38}$ Note that in our model, the state's coercive capacity is exogenous and captured by the parameter $\beta$, which measures the fighting effectiveness of Great Council members (nobles) relative to non-members. The build-up of state capacity could be introduced into our model by having $\beta$ be a concave function of the costly effort devoted by nobles to building coercive capacity. There would then be some optimal combination of co-option (i.e., Enlargement) and coercion that would be used by families in the Great Council to accomplish the Serrata.

39 "The great galleys were at the same time [after 1299] made subject to close regulation by the state which elected the commanding officer of the galley fleets and determined the crew, the equipment, and the measures of the galleys, the number to be sent on any particular voyage, the time of sailing and returning, the freight rates to be charged, and innumerable other details" Lane (1934, page 14).
} 
publicly owned galleys that were auctioned off to private operators. In 1329, this system became a permanent feature of the galley fleet to Greece, Constantinople and the Black Sea. In 1331, it was extended to the galley fleet to outremare (the rest of the Western Mediterranean) and a decade later to the Flanders galley fleet. See Lane (1963).

There were several reasons for the reorganization, including the naval needs of the Commune, the invention of the great galley and the expansion of the Arsenal; however, it is abundantly clear that the reorganization generated huge rents for insiders. "These state galley fleets were protected against the competition of either round ships or privately owned Venetian galleys which might go on the same voyage" Lane (1934, page 14). See Lane (1963, page 189) for details. Further, the insiders who claimed these rents were friends of the Great Council. To quote O'Connell (2009, page 5): "It was in the administration of the state-run galley fleets that individual economic interest and public office most obviously intertwined." The fact that the reorganization came on the heels of the Serrata is no coincidence.

A key feature of the reorganization was that space on these state-owned galleys was now auctioned off each season. The bidders were typically consortia of very rich nobles. For example, a consortium headed by Marino Capello operated seven of the eight galleys to Flanders in $1333 .^{4^{\circ}}$ Why did the rich dominate? The proximate reason is that galleys required huge up-front financing so that successful bidders were required to post a large 'performance' bond as a guarantee of their commitment. Yet private galleys made do without performance bonds and these bonds could have been financed by state loans. The deeper reason is that, as we argued in our model, the post-Serrata Commune had every reason to erect such wealth-based barriers to participation in long-distance trade. ${ }^{41}$

In addition to sewing up the galley trade, the noble-run Commune directly restricted who could trade on the most lucrative routes. In 1324, just one year after the completion of the Serrata, a law was introduced (the Capitulare Navigantium) that forbade any merchant from shipping wares with a value in excess of the merchant's assessed wealth. Wealth assessments were used by the Commune to determine taxes and, since only the very wealthy paid taxes, the Capitulare Navigantium excluded the poor from long-distance trade. Indeed, it ensured that only the very richest merchants (those with large assessments) could engage in large-scale long-distance trade. The Officium de Navigantibus was created to enforce the new law. It was initially active for less than a year, but was reinstated in 1331-38 and again in 1361-1363 (Cessi, 1952).42

To examine the impact of the 1324 Capitulare Navigantium (as well as the reorganization of the galley trade), we look at the characteristics of merchants who used the colleganza before and after

${ }^{40}$ Lane (1963, page 195). All participants named in Lane (1963) were nobles.

${ }^{41}$ Lane (1963, page 197) specifically raises the question of why the Commune did not provide financing loans so as to encourage greater use of its expensive galleys - especially since it could have done so "without placing any strain on its credit." Lane explains this by pointing out that in the period 1313-1334 the Commune was pre-occupied with retiring its debt and so did not want to issue new loans. What Lane does not mention is that by retiring old debt, the Commune drove up the price of its debt by about 50\% (Mueller, 1997, graph 11.1), thus creating enormous capital gains for the rich nobles that held the vast majority of this debt. On the link between public debt and merchant-run cities see Stasavage (2011).

${ }^{42}$ We note that this interpretation of the Capitulare Navigantium is not standard in the literature. Historians see the Capitulare Navigantium as a minor event that prevented tax evasion and excluded non-citizens from long-distance trade e.g., Cessi (1952). In appendix 8 we show that such positions are incomplete. 
1324 to see (a) whether non-nobles were excluded and (b) whether, among nobles, usage shifted to those with greater political power (as measured by seat shares in the Great Council).

We begin by examining the colleganza contracts that have survived for the period 1073-1342. These appear in Morozzo della Rocca and Lombardo (1940, 2 volumes), Lombardo and Morozzo della Rocca (1953), Tiepolo (1970), and Sebellico (1973, 2 volumes). These volumes are collections of all types of commercial contracts, such as dowries, wills, lease agreements, loans, settlements, sales of slaves, etc. We first identify which of these commercial documents are colleganza or settlements of a colleganza. In some of these volumes, each contract is preceded by an editorial header giving the date, place and type of contract; however, these headers are often vague or inaccurate so we instead reviewed each of the 2,833 documents individually. Identification is tricky and requires a considerable investment in time to learn how to distinguish colleganza from other related contracts. ${ }^{43}$ In all we identified 381 colleganza for the period 1073-1342. Some of these colleganza have also been coded by Kedar (1976) and by González de Lara (2008): Kedar (1976), examines contracts dated 1240-1261 and 1310-1323, and González de Lara (2008), examines contracts dated 1121-1261; neither codes contracts dated after the Capitulare Navigantium. We have benefitted enormously from numerous discussions with González de Lara on the coding of colleganza.

For each colleganza we identify the sedentary and travelling merchants and match their family names to the names of families with seats in the Great Council. This involves standardizing family names using the same procedure described in footnote 31 above. We have data on Great Council membership and seat shares for 1261-1295. From 1297 on, Raines (2004, appendix A) lists the names of Venetian nobles, which gives us the list of families present in the Great Council (but not their seat shares). ${ }^{44}$ From here on in we refer to merchants with family members in the Great Council as 'nobles' and to all others as 'commoners.'

Table 1 presents the results. Column 1 displays the period. The reader will immediately notice one bit of historical irony - no colleganza have survived for 1261-1295 i.e., for the period with Great Council membership records. This is not crucial because our primary interest is in comparing the pre- and post-1324 periods. The grey-shaded rows are the years in which the Officium de Navigantibus was in operation (1324 and 1331-1338). Recall that the Officium was in charge of enforcing the Capitulare Navigantium.

\footnotetext{
${ }^{43}$ Colleganza contracts are most easily identified by two clauses. The first states that in the event of profits, the travelling merchant receives a share of these profits e.g., 'Reliquam quartam partem in me retinere debeam.' The second states that loses are borne by the sedentary merchant out of his capital - the typical phrase is 'suprascriptum tuum habere debet esse in tuo periculo maris et gentis' ('Your aforesaid goods are to remain at your own risk from sea and people.') See the colleganza in figure 2. Care must be taken because these phrases are not always present. In particular, the contracts become shorter and shorter over time and often formulaic expressions are truncated with 'etc.' Settlements of colleganza require a careful reading to understand what type of contract is being settled. The most common difficulty is distinguishing between a colleganza and a sea loan. The latter usually has the phrase 'salve in terra,' meaning that the travelling merchant is required to repay the loan even if there are losses. Sometimes both the original colleganza and its settlement have survived, in which case we count only the original contract; however, most often only one of the two has survived, in which case we date the contract to the date of the original colleganza (which is almost always specified in the settlement). There are two settlements of colleganza for which only a fragment of the original parchment not including the names of the merchants has survived, so we leave these out. There are a small number of other related contracts dealing with the transfer of colleganza obligations. We include these as well.

${ }^{44}$ As one would expect from our history of the Serrata, we pick up very few additional names from Raines (2004) because most families were already in the Great Council in 1261-1295.
} 
Table 1: Commoner Involvement in Colleganza

\begin{tabular}{|c|c|c|c|c|c|}
\hline (1) & (2) & (3) & (4) & (5) & (6) \\
\hline Period & $\begin{array}{l}\text { Number of } \\
\text { surviving } \\
\text { colleganza }\end{array}$ & $\begin{array}{l}\text { Number of } \\
\text { colleganza } \\
\text { involving } \\
\text { commoners }\end{array}$ & $\begin{array}{c}\% \text { of } \\
\text { colleganza } \\
\text { involving } \\
\text { commoners }\end{array}$ & $\begin{array}{l}\text { Median merchant's } \\
\text { family seats } \\
\text { per session in } \\
\text { the Great Council }\end{array}$ & $\begin{array}{l}\text { Officium de } \\
\text { Navigantibus }\end{array}$ \\
\hline 1073-1203 & 72 & 29 & $40 \%$ & 1.7 & \\
\hline 1204-1220 & 56 & 23 & $41 \%$ & 0.9 & \\
\hline $1221-1240$ & 79 & 43 & $54 \%$ & 0.6 & \\
\hline $1241-1261$ & 59 & 28 & $47 \%$ & 0.8 & \\
\hline 1310-1323 & 83 & 22 & $27 \%$ & 2.9 & \\
\hline 1324 & 1 & 0 & $0 \%$ & 1.8 & In force \\
\hline 1325-1330 & 19 & 1 & $5 \%$ & 4.7 & \\
\hline 1331-1338 & 10 & 0 & $0 \%$ & 5.3 & In force \\
\hline 1339-1342 & 2 & 0 & $0 \%$ & 13.4 & \\
\hline
\end{tabular}

Column 2 reports the number of colleganza that have survived for each period. Column 3 reports the number of colleganza in which at least one of the merchants was a commoner i.e., a merchant with no family in the Great Council from 1261 onwards. Column 4 reports these colleganza as a share of all colleganza in the period. Comparing 1310-1323 with all later periods, there is a sharp drop in commoner participation after the Capitulare Navigantium. During 1310-1323, commoners participated in $27 \%$ of all colleganza. After 1324 there is only a single colleganza with commoner participation. 45

By 1310, Venice was already deep into the Serrata so we might expect the process of commoner exclusion to have been well on its way. That is, we might expect that $27 \%$ is too low of a number. It is therefore useful to look further back, to 1241-1261 and even further. Indeed, commoner participation was higher in earlier years, making the 1324 break starker. Commoners were involved in $47 \%$ of all colleganza during 1241-1261. As far back as 1073-1203, commoners were involved in $40 \%$ of all colleganza. ${ }^{46}$

Column 5 moves the discussion away from commoner participation and to the power of the nobles that participated. In each period we draw up a list of all the merchants involved in a colleganza. We then assign each of these merchants a 'power score,' which is simply his family's number of seats in the Great Council. (The number of seats is the family's average number of seats per session during 1261-1295.) We then examine how power scores of the median merchant evolved across periods. Similar results hold for averages. The first observation from column 5

\footnotetext{
45This 1326 colleganza is a bizarre 'coals to Newcastle' colleganza. The non-noble travelling merchant is carrying mink fur to Tana on the Black Sea on behalf of a nobleman and his partner, despite the fact that Tana was a centre for the fur trade!

${ }^{46}$ In his excellent book, Kedar (1976) also documents this decline in commoner participation in colleganza between 1240-1261 and 1310-1323. The only problem with his analysis is that he is unclear about how he defines nobility - he certainly does not define it by reference to Great Council participation.
} 
is that the median number of seats is positive i.e., the median merchant had family members in the Great Council. Prior to 1310, the median merchant's family presence in the Great Council was modest. For example, in 1241-1261, it was less than one, which signals that this median family alternated in and out of the Council. During the Serrata but after the Enlargement (1310-1323), the median merchant's family held almost three seats. After the Serrata (1325-1338), it jumped even higher, to about five seats. Thus, after the Serrata and, especially after the Capitulare Navigantium, use of the colleganza shifted to more and more powerful families. ${ }^{47} 48$

To summarize, the Capitulare Navigantium and the reorganization of the galley trade dramatically reduced the economic competition faced by the most powerful families, competition both from commoners and from less-powerful nobles. Surprisingly, the connection between this economic Serrata and the political Serrata has not been properly emphasized. Finally, we note that our interpretation is not standard in the literature. Lane emphasizes that the reorganization of the galley trade was a major event with important negative long-term consequences (see below), but he does not tie it to the Serrata. Further, with the exception of Kedar (1976), historians have described the Capitulare Navigantium as a minor event. (Again, see appendix 8 for details.)

\section{Epilogue: The Demise of Venice as a Maritime Power}

The Serrata marked the beginning of the end of Venice's maritime power. "Never again was Venice so largely a maritime nation as it had been in the thirteenth century" (Lane, 1973, page 170). And yet well into the sixteenth century Venice produced enough wealth to afford the likes of Bellini and Palladio, and to build the opulent palazzos that made tourism Venice's main industry. Was it a mistake, then, for the oligarchs to push through this political and economic closure?

Oligarchization did indeed contribute to Venice's affluence. The Italian communes of the time were wracked by violent internal rivalries between clans and avoiding this was a paramount concern of all Venetians. See Lane (1971, pages 259-260), Greif (2006a, section 6.4.2) and González de Lara et al. (2008). Putting a lid on inter-clan rivalry allowed Venice's oligarchs to sustain co-operation so that they could exploit the rents from long-distance trade for longer, well into the sixteenth century.

Lane viewed the reorganization of the galley trade and Venice's strong citizenship requirements through the lens of this concern about the destabilizing effects of inter-clan rivalry. "Communal ownership of galleys expressed the solidarity of the Venetian nobility and strengthened that solidarity. The system of annual auctions ... was a vital element in giving to the Venetian government

\footnotetext{
47The table 1 numbers for $1310-1342$ are accurate and establish our point. The pre-1261 numbers are less accurate. We explain the problem by way of two examples. (a) If a merchant in 1240 whose family had never sat in the Great Council entered the Great Council in 1261 he is classed as a noble, thus leading us to understate commoner participation. (b) If a merchant in 1240 was in the Great Council in 1240 but not after 1261 he is incorrectly classified as a commoner, thus leading us to overstate commoner participation. It is hard to see how such misclassifications could account for the difference between $47 \%$ and $0 \%$ or even between $47 \%$ and $27 \%$. However, as a robustness check we also classified a merchant as noble if his family name appears in Rösch's (1989) list of families that were prominent from the tenth century through to 1141 . This reduces commoner participation rates in $1073-1261$ by just 6 percentage points, from $46 \%$ to $40 \%$.

${ }^{48}$ Our results should not be misconstrued to mean that only the rich traded. There continued to be trading by commoners in less profitable routes (e.g., Apellániz, forthcoming) and our results mean that it was now much more difficult for commoners to break into the most lucrative segments of long-distance trade.
} 
the efficiency and stability which distinguished it from so many other Italian city-states of the fourteenth century" Lane (1973, page 203). It is difficult for an economist to make formal sense of such quotes; fortunately, González de Lara (2008) helps us out here. She argues that from the 1180s to the 1220s, Venice built a set of institutions that made it costly for merchants to embezzle the funds of investors. The key to sustaining such cooperation in capital markets was rents: Merchants who misbehaved were barred from participating in Venice's long-distance trade and were thus denied supra-normal profits. González de Lara then interprets events of the late thirteenth and early fourteenth centuries, such as tougher citizenship requirements and the Capitulare Navigantium, as designed to maintain the rents needed to sustain cooperation in capital markets.

Our work dovetails with González de Lara's emphasis on the need for rents to sustain cooperation. We extend her logic from financial markets to political and economic markets. For example, our work explains why political and economic cooperation was sustained for so long. First, recall that the Great Council was enlarged (1310) before it was permanently closed (1323). That is, the ruling elite prevented instability by co-opting its most powerful opposition. Second, economic closure allowed the ruling elite to increase their share of the rents from long-distance trade. That is, more rents were available to sustain cooperation. Third, and more dynamically, the economic closure dampened the emergence of powerful new 'outsiders' - including both non-citizens and the domestic nouveau riche - who could upset the balance of power and destabilize cooperation.

Sustaining cooperation came at a long-run cost. Economic closure was biased towards the richest merchants and eventually led to an overly concentrated distribution of power. Almost none of the families that entered the Great Council during the Enlargement of 1310 remained by 1410. The many efforts to replenish these lost families were mostly blocked. By the mid-seventeenth century there was a shortage of capable nobles for the highest posts and over the next hundred years the number of nobles shrunk by half e.g., Lane (1973, pages 427-431). The resulting extreme concentration of political and economic power is widely viewed as the ultimate cause of Venice's demise. In fact it was the proximate cause: The ultimate cause was the political and economic closure that we have documented.

This paper is about the impact of international trade on domestic institutions. Given the limits of space, the issue we have chosen to address is not about why Venice survived, but about the impact of the political and economic closure on Venice's institutional dynamism. Long after the mid-fourteenth century, we continue to see Rise-of-the-West institutional dynamism in the major territorial states of Western Europe and even in cities such as Genoa or Barcelona. Less so in Venice. To the contrary, we see the negative consequences associated with oligarchization, including rentseeking behaviour, misallocation of talent, a decline in entrepreneurship, and technical change that is biased towards the needs of the oligarchs e.g., Acemoglu (2008).

Examples abound. In the 1320s, the Arsenal was the largest industrial centre in Europe and produced a steady stream of innovations designed to improve galley performance, including some by Galilleo. Yet much of this technical change was directed towards increasing oligarch profits from the Levant trade; it never translated into the large number of maritime innovations that would propel Western Europe into the Age of Discovery. In the 1320s, Venice was a world leader in banking, but lost its position thereafter, at least in part because powerful individuals 
monopolized the sector e.g., Fratianni and Spinelli (2006, page 271). In the 1320s, Venice was a dominant maritime power, yet in 1344-1358 it lost control over much of the Dalmation coast and in the Battle of Chiogga (1379-1380) Venice was almost invaded by a Genoese naval force. The Battle is instructive of the problems with entrepreneurialism under an oligarchy. The Venetian force was led by an oligarch with relatively little naval experience. It was only under the threat of mutiny by Venetian sailors that Venice re-instated Vettor Pisani, an experienced naval commander who was languishing in jail. We see the same problem again almost a century later immediately after Venice ended its long period of commercial co-operation with the Ottomans. In 1470, the siege of Venice's most important stronghold in the Eastern Mediterranean (Negroponte) should have been broken easily by a large Venetian relief force was. However, the force was headed by a commander with little naval experience and he retreated without a fight. Lane blames Venice's failures in the Eastern Mediterranean on the fact that after the Serrata family connections meant more than merit-based progress through a professional administration: "She did not develop a hierarchy of real professionals supported by a naval bureaucracy. Discpline and appointments to high commands depended on the votes of fellow nobles in Venice's governing councils" (Lane, 1973, page 249).

Venice's loss of institutional dynamism is best conveyed by the colleganza. It continued to be widely used in Barcelona and Genoa. In the latter, it slowly evolved into an on-going partnership, most famously the Bank of Saint George. It then further evolved into the great joint-stock companies of the Age of Discovery. Yet in Venice it never evolved beyond a simple partnership that was legally obliged to dissolve after two years. The reason for this institutional stagnation was the reorganization of the galley trade. A modern company is an on-going organization that carries its assets forward. In the galley trade, the key tangible asset was the ship and the natural evolution of the colleganza would have involved ownership of a ship, which in turn would have created a more permanent, modern-looking organization. But in Venice, public ownership of galleys prevented this development of the colleganza (Lane, 1963). In short, the economic and political closures associated with the Serrata brought an end to the institutional dynamism that had served Venice so well for so long.

\section{Conclusion}

Through a series of fortuitous events beginning in 8oo, Venice was launched on a path of political independence for over 500 years. This allowed us to examine the Venetian response to Europe's great wave of medieval globalization, the Commercial Revolution. Venice's unique geographic and cultural location between Byzantium and Western Europe benefited its Venetian merchants, especially after the opening of Mediterranean shipping lanes to Christian shipping in 976 and the preferential trade arrangements with Byzantium after 1082. The Venetian (Fourth Crusade) conquest of Constantinople in 1204 created a Venetian colonial system in the Eastern Mediterranean that massively expanded Venetian trade. Between 976 and 1297, rapidly rising long-distance trade empowered Venetian merchants, who used their clout to push for novel institutional arrangements. In 1032 they reigned in the Dogeship (it stopped being hereditary) and in 1172 they 
created a parliament (the Great Council). That is, they successfully pushed for improved property rights institutions. Further, they showed remarkable dynamism in developing new contracting institutions. We examined one of these in detail, the colleganza, and showed how it promoted income mobility and with it, political mobility.

Over time, a group of particularly rich merchants emerged and, starting in 1297, they used their resources to block political and economic competition. In particular, they made parliamentary participation hereditary and erected barriers to participation in the most lucrative segments of long-distance trade. We documented this rise and fall of institutional dynamism using a unique database on the names of 8,103 parliamentarians and their families' use of the colleganza. A single simple lesson emerged: International trade can have both positive and negative impacts on domestic institutions. In medieval Venice it had both.

\section{References}

Acemoglu, Daron. 2003. Why not a political Coase theorem? Social conflict, commitment, and politics. Journal of Comparative Economics 31(4):620-652.

Acemoglu, Daron. 2008. Oligarchic vs. democratic societies. Journal of the European Economic Association 6(1):1-44.

Acemoglu, Daron, María Angélica Bautista, Pablo Querubín, and James A. Robinson. 2008. Economic and political inequality in development: The case of Cundinamarca, Colombia. In Elhanan Helpman (ed.) Institutions and Economic Performance. Cambridge: MA: Harvard University Press, 181-245.

Acemoglu, Daron, Simon Johnson, and James A. Robinson. 2005. The rise of Europe: Atlantic trade, institutional change and economic growth. American Economic Review 95(3):546-579.

Acemoglu, Daron and James A. Robinson. 2006. Economic Origins of Dictatorship and Democracy. Cambridge, UK: Cambridge University Press.

Acemoglu, Daron and James A. Robinson. 2012. Why Nations Fail: The Origins of Power, Prosperity, and Poverty. New York, NY: Crown Publishing.

Apellániz, Francisco. forthcoming. Transgressing boundaries in cross-cultural trade: Lower-rank merchants in the Medieval Eastern Mediterranean. Journal of Interdisciplinary History .

Banerjee, Abhijit V. and Andrew F. Newman. 1993. Occupational choice and the process of development. Journal of Political Economy 101(2):274-298.

Berman, Harold J. 1983. Law and Revolution: The Formation of the Western Legal Tradition. Cambridge, MA: Harvard University Press.

Berman, Harold J. and Colin Kaufman. 2004. Law of international commercial transactions (Lex Mercatoria). Harvard International Law Journal 19(1):221-277.

Berto, Luigi Andrea (ed.). 1999. Historia ducum Veneticorum. In Testi storici veneziani (XI-XIII secolo). Padova, Italy: cleup. Available from Archivio della latinità italiana del Medioevo: http://www.uan.it/alim/testi/xiii/alimhistorducumvenetxiiistopro2.htm. 
Besley, Timothy, Konrad Burchardi, and Maitreesh Ghatak. 2012. Incentives and the de Soto effect. Quarterly Journal of Economics 127(1):237-282.

Besta, Enrico and Riccardo Predelli (eds.). 1901. Gli statuti civili di Venezia anteriori al 1242. Venice, Italy: Federico Visentini Editore.

Brown, Horatio F. 1920. The Venetians and the Venetian quarter in Constantinople to the close of the twelfth century. Journal of Hellenic Studies 40(Part 1):68-88.

Byrne, Eugene H. 1970. Genoese Shipping in the Twelfth and Thirteenth Centuries. Cambridge, ma: The Mediaeval Academy of America.

Castagnetti, Andrea. 1992a. La Societá Veneziana nel Medioevo I, Dai Tribuni ai Giudici. Verona, Italy: Libreria Universitaria Editrice.

Castagnetti, Andrea. 1992b. Famiglie e affermazione politica. In Lellia Cracco Ruggini, Mario Pavan, Giovanni Cracco, and Gherardo Ortalli (eds.) Storia di Venezia I, Origini-Etá Ducale. Rome, Italy: Istituto dell'Enciclopedia Italiana, 613-644.

Cessi, Roberto (ed.). 1931-1950. Deliberazioni del Maggior Consiglio di Venezia, 3 volumes. Bologna, Italy: Nicola Zanichelli.

Cessi, Roberto. 1952. L "Officium de Navigantibus "e i sistemi della politica commerciale Veneziana nel secolo xIV. In Roberto Cessi (ed.) Politica ed Economica di Venezia nel Trecento. Rome, Italy: Edizioni di Storia e Letteratura, 23-61.

Cessi, Roberto. 1966. Venice to the eve of the fourth crusade. In D.M. Nicol and G. Cowan (eds.) The Cambridge Medieval History, Volume IV: The Byzantine Empire, Part I: Byzantium and Its Neighbours. Cambridge, UK: Cambrige University Press, 250-274.

Chandler, Tertius. 1987. Four Thousand Years of Urban Growth: An Historical Census. Lewiston, NY: St. David's University Press.

Choniates, Niketas. 1984. O City of Byzantium: Annals of Niketas Choniates. Detroit: Wayne State University Press. Translated by Harry J. Magoulias.

De Long, J Bradford and Andrei Shleifer. 1993. Princes and merchants: European city growth before the Industrial Revolution. Journal of Law and Economics 36(2):671-702.

de Roover, Raymond. 1965. The organization of trade. In M. M. Postan, E. E. Rich, and Edward Miller (eds.) The Cambridge Economic History of Europe, Volume 3: Economic Organization and Policies in the Middle Ages. Cambridge, uK: Cambridge University Press, 70-86.

de Soto, Hernando. 1989. The Other Path: The Invisible Revolution in the Third World. New York, NY: HarperCollins.

Do, Quy-Toan and Andrei A. Levchenko. 2009. Trade, inequality, and the political economy of institutions. Journal of Economic Theory 144(4):1489-1520.

Fratianni, Michele and Franco Spinelli. 2006. Italian city-states and financial evolution. European Review of Economic History 10(03):257-278.

Galor, Oded and Joseph Zeira. 1993. Income distribution and macroeconomics. Review of Economic Studies 6o(1):35-52. 
Ghatak, Maitreesh and Neville NienHuei Jiang. 2002. A simple model of inequality, occupational choice, and development. Journal of Development Economics 69(1):205-226.

González de Lara, Yadira. 2008. The secret of Venetian success: A public-order, reputation-based institution. European Review of Economic History 12(3):247-285.

González de Lara, Yadira, Avner Greif, and Saumitra Jha. 2008. The administrative foundations of self-enforcing constitutions. American Economic Review Papers and Proceedings 98(2):105-109.

Greif, Avner. 1992. Institutions and international trade: Lessons from the Commercial Revolution. American Economic Review 82(2):128-133.

Greif, Avner. 1994. Cultural beliefs and the organization of society: A historical and theoretical reflection on collectivist and individualist societies. Journal of Political Economy 102(5):912-950.

Greif, Avner. 2005. Commitment, coercion, and markets: The nature and dynamics of institutions supporting exchange. In Claude Menard and Mary M. Shirley (eds.) Handbook for New Institutional Economics. Norwell: MA: Kluwer Academic Publishers, chapter 28.

Greif, Avner. 2006a. Institutions and the Path to the Modern Economy: Lessons from Medieval Trade. Cambridge, uK: Cambridge University Press.

Greif, Avner. 2006b. The birth of impersonal exchange: The community responsibility system and impartial justice. Journal of Economic Perspectives 20(2):221-236.

Greif, Avner. 2008. The impact of adminstrative power on political and economic developments: Toward a political economy of implementation. In Elhanan Helpman (ed.) Institutions and Economic Performance. Cambridge: MA: Harvard University Press, 17-63.

Greif, Avner and David D. Laitin. 2004. A theory of endogenous institutional change. American Political Science Review 98(4):633-652.

Greif, Avner, Paul Milgrom, and Barry R. Weingast. 1994. Coordination, commitment, and enforcement: The case of the merchant guild. Journal of Political Economy 102(4):745-776.

Hazlitt, W. Carew. 1966. The Venetian Republic, Its Rise, its Growth, and its Fall A.D.409-1797. New York, NY: AMS Press, Inc.

Jha, Saumitra. 2010. Financial innovations and political development: Evidence from Revolutionary England. Research Paper No. 2005, Stanford University Graduate School of Business.

Jones, Benjamin F. and Benjamin A. Olken. 2009. Hit or miss? The effect of assassinations on institutions and war. American Economic Journal: Macroeconomics 1(2):55-87.

Kadens, Emily. 2004. Order within law, variety within custom: The character of the medieval merchant law. Chicago Journal of International Law 5(1):39-66.

Kedar, Benjamin Z. 1976. Merchants in Crisis: Genoese and Venetian Men of Affairs and the FourteenthCentury Depression. New Haven, cr: Yale University Press.

Kohn, Meir. 2005. The Origins of Western Economic Success: Commerce, Finance, and Government in Preindustrial Europe. Mimeo, Dartmouth University.

Landau, Peter. 2004. The development of law. In David Luscombe and Jonathan Riley-Smith (eds.) New Cambridge Medieval History, Volume 4, c.1024-c1198 Part I. Cambridge, uK: Cambridge University Press, 113-147. 
Lane, Frederic C. 1963. Venetian merchant galleys, 1300-1334: Private and communal operation. Speculum 38(2):179-205.

Lane, Frederic C. 1966. Rythm and rapidity of turnover in Venetian trade of the fifteenth century. In Venice and History: The Collected Papers of Frederic C. Lane. Baltimore, MD: John Hopkins University Press, 109-127.

Lane, Frederic C. 1971. The enlargement of the Great Council of Venice. In J. G. Rowe and W. H. Stockdale (eds.) Florilegium Historiale: Essays Presented to Wallace K. Ferguson. Toronto, Canada: University of Toronto Press, 236-74.

Lane, Frederic C. 1973. Venice: A Maritime Republic. Baltimore, MD: John Hopkins University Press.

Lane, Frederic C. and Reinhold C. Mueller. 1985. Money and Banking in Medieval and Renaissance Venice: Coins and Moneys of Account (Volume I). Baltimore, MD: Johns Hopkins University Press.

Lane, Frederic Chapin. 1934. Venetian Ships and Shipbuilders of the Renaissance. Baltimore, MD: Johns Hopkins University Press.

Levchenko, Andrei A. forthcoming. International trade and institutional change. Journal of Law, Economics, and Organizations .

Lombardo, Antonino and Raimondo Morozzo della Rocca (eds.). 1953. Nuovi Documenti del Commercio Veneto dei Secoli XI-XIII. Venice, Italy: Deputazione di storia patria per le Venezie.

Lopez, Robert S. 1971. The Commercial Revolution of the Middle Ages, 950-1350. Cambridge, uK: Cambridge University Press.

Lopez, Robert S. and Irving W. Raymond. 1967. Medieval Trade in the Mediterranean World. New York, NY: Columbia University Press.

Madden, Thomas F. 2003. Enrico Dandolo and the Rise of Venice. Baltimore, MD: Johns Hopkins University Press.

Milgrom, Paul R., Douglass C. North, and Barry R. Weingast. 1990. The role of institutions in the revival of trade: The law merchant, private judges, and the Champagne fairs. Economics and Politics 2(1):1-23.

Morozzo della Rocca, Raimondo and Antonino Lombardo (eds.). 1940. Documenti del Commercio Veneziano nei Secoli XI-XIII (2 vols.). Fonti per la storia dell'Italia medievale. Regesta Chartarum. Turin, Italy: Istituto storico per il Medio Evo.

Mozzato, Andrea. 2004. Problems and possibilities of constructing a research database: The Venetian case. Storia di Venezia, Rivista 2:1-38.

Mueller, Reinhold C. 1997. Money and Banking in Medieval and Renaissance Venice: Banks, Panics, and the Public Debt 1200-1500 (Volume II). Baltimore, MD: Johns Hopkins University Press.

Nicol, Donald M. 1988. Byzantium and Venice: A Study in Diplomatic and Cultural Relations. Cambridge, uK: Cambridge University Press.

North, Douglass C. 1990. Institutions, Institutional Change and Economic Performance. Cambridge, UK: Cambridge University Press.

North, Douglass C. and Robert Paul Thomas. 1973. The Rise of the Western World: A New Economic History. Cambridge, uK: Cambridge University Press. 
Norwich, John Julius. 1977. A History of Venice. London: Penguin Books.

O'Connell, Monique. 2009. Men of Empire: Power and Negotiation in Venice's Maritime State. Baltimore, MD: Johns Hopkins University Press.

Pryor, John H. 1981. Business Contracts of Medieval Provence. Toronto, Canada: Political Institute of Mediaeval Studies.

Pryor, John H. 1987. Commerce, Shipping and Naval Warfare in the Medieval Mediterranean. London, UK: Variorum Reprints.

Pryor, John H. 1988. Geography, Technology and War: Studies in the Maritime History of the Mediterranean, 649-1571. Cambridge, UK: Cambridge University Press.

Queller, Donald E. 1986. The Venetian Patriciate: Reality versus Myth. Urbana, IL: University of Illinois Press.

Radding, Charles M. 1988. The Origins of Medieval Jurisprudence: Pavia and Bologna, 850-1150. New Haven, ст: Yale University Press.

Radding, Charles M. and Antonio Ciaralli. 2006. The Corpus Iuris Civilis in the Middle Ages: Manuscripts and Transmission From the Sixth Century to the Juristic Revival. Leiden, Netherlands: Brill.

Raines, Dorit. 2004. Cooptazione, aggregazione e presenza al maggior consiglio: le casate del patriziato Veneziano, 1297-1797. Storia di Venezia, Rivista 1:1-35.

Rajan, Raghuram G. and Luigi Zingales. 2003. The great reversals: the politics of financial development in the twentieth century. Journal of Financial Economics 69(1):5-50.

Robbert, Louise Buenger. 1994. Money and prices in thirteenth-century Venice. Journal of Medieval History 20(4):373-390.

Robbert, Louise Buenger. 1999. Domenico Gradenigo: A thirteenth-century Venetian merchant. In Donald E. Queller, Ellen E. Kittell, and Thomas F. Madden (eds.) Medieval and Renaissance Venice. Urbana, IL: University of Illinois Press, 27-48.

Romanin, Samuele. 1854. Storia documentata di Venezia, Tomo II. Venezia: Pietro Naratovich Tipgrafo Editore.

Rösch, Gerhard. 1989. Der Venezianische Adel bis zur Schliessung des Grossen Rates: zur Genese einer Führungsschicht. Sigmaringen: Thorbecke.

Rösch, Gerhard. 2000. The Serrata of the Great Council and Venetian society, 1286-1323. In John Martin and Dennis Romano (eds.) Venice Reconsidered, The History and Civilization of an Italian City-State 1297-1797. Baltimore, MD: Johns Hopkins University Press, 67-88.

Rotman, Youval. 2009. Byzantine Slavery and the Mediterranean World. Cambridge, MA: Harvard University Press.

Ruggiero, Guido. 1980. Violence in Early Renaissance Venice. New Brunswick, NJ: Rutgers University Press.

Sebellico, Andreina Bondi (ed.). 1973. Felice de Merlis, Prete e Notaio in Venezia ed Ayas (1315-1348), 2 volumes. Venice, Italy: Comitato per la Pubblicazione delle Fonti Relative alla Storia di Venezia. 
Stasavage, David. 2011. States of Credit: Size, Power, and the Development of European Polities. Princeton: Princeton University Press.

Tiepolo, Maria Francesca (ed.). 1970. Domenico Prete di S. Maurizio, Notaio in Venezia (1309-1316). Venice, Italy: Comitato per la Pubblicazione delle Fonti Relative alla Storia di Venezia.

Weber, Max. 2003 [1889]. The History of Commercial Partnerships in the Middle Ages. Lanham, MD: Rowman \& Littlefield.

Wickham, Chris. 2003. Courts and conflict in twelfth-century Tuscany. Oxford, uk: Oxford University Press.

\section{Appendix: On the Interpretation of the Capitulare Navigantium}

The Capitulare Navigantium required participants in long-distance trade to pay taxes and this in turn required participants to be citizens. Historians have therefore treated the Capitulare Navigantium as another in a series of measures designed to exclude foreigners from Venetian long-distance trade e.g., Lane (1973, pages 140 and 185) and González de Lara (2008, section 4.2). There is no doubt that the Capitulare played this role and we have made this connection in section 7 . However, this cannot be the full story. If the Capitulare Navigantium was solely intended to target foreign investors then Venetian travelling merchants (who were not investors) would not have been affected. Yet travelling merchants were very often commoners before 1324 and after 1324 there is the single colleganza with a commoner travelling merchant discussed above. ${ }^{49}$ Further, the largest group of foreign investors were Germans, who operated out of their Fondaco next to the Rialto bridge. Venice was clearly concerned that Germans were circumventing the restrictions on foreigners by using Venetian citizens as 'fronts.' To prevent this, a stiff import duty was imposed on Germans who brought German coins to Venice. This duty went into effect in 1277, was repealed in 1332 and was reestablished in 1338 (Lane and Mueller, 1985, pages 193-194). That is, the duty was cancelled in the years when the Officium de Navigantibus was in operation (1331-1338)! The implication is clear: The Capitulare Navigantium was more than just a restriction on foreign participation in longdistance trade.

Is it possible that the Capitulare's impact on less-wealthy Venetian citizens was an oversight in a poorly written piece of xenophobic legislation? No. The wealth restrictions must have been intentional because they were onerous. They forced rich Venetian nobles to repeatedly petition the Senate for exemptions for their children: exemptions were needed because children were too young to be citizens (under 25) and not wealthy enough to pay taxes. See Cessi (1952, page 41). The fact that the wealth restrictions were onerous means that they were not an oversight. Rather, they were an important part of the Capitulare..$^{0}$

\footnotetext{
${ }^{49}$ Before $132425 \%$ of travelling merchants documented in table 1 were commoners whose families we never see in the Great Council - not even after the Enlargement.

${ }^{50}$ Lane conceeds this point in only one brief comment: "Rich, well-established merchants were sometimes able to use antagonism towards foreign competition so as to restrict the activities of up-and-coming Venetians" (Lane, 1973, page 144).
} 